\title{
Evaluating the Effect of Supernatant Collected from the Culture of Bifidobacterium bifidum on the Increase of Angiogenesis in Acute Wound Healing
}

\author{
Pegah Moussavi Amin¹, Akram Sadat Tabatabaee Bafroee ${ }^{1}$ Babak Khalili Hadad 2* iD
}

1.Department of Biology, East Tehran Branch, Islamic Azad University, Tehran, Iran

2. Department of Biology, Roudehen Branch, Islamic Azad University, Roudehen, Iran

\section{ABSTRACT}

Background and Aim: Wound healing is the result of interactions between cytokines, growth factors, blood, and extracellular matrix. Facing this challenging issue has become one of the essential concerns in health and medical fields, needing different remedies. One of the newest treatments in wound healing is the application of probiotic bacteria. Therefore, the aim of the current study is to evaluate the effect of Bifidobacterium bifidum probiotic bacteria on acute wound healing and exploring the potential of their supernatant on increasing angiogenesis in female mice in the form of biological dressing.

Materials and Methods: 44 female BALB/c mice were studied into six groups in two phases of 7 and 14 days. After the wounding process, wound sizes were measured by a digital caliper every 48 hours. Mice were dressed and treated. Histological samples were studied, and the results were analyzed statistically.

Results: Bifidobacterium $b$. probiotic bacteria not only show exciting potential as a therapeutic and effective agent but also our examination proved that application of this probiotic plus Aloe vera hydrogel (experimental group 1) can significantly reduce the wound healing duration and increases angiogenesis $(P<0.05)$

Conclusion: According to the findings of this study, the designed biological dressing, including Bifidobacterium $b$. supernatant and Aloe vera hydrogel, can be used in acute wound healing after further studies.

Keywords: Probiotic, Bifidobacterium bifidum, Acute wound healing, Culture supernatant

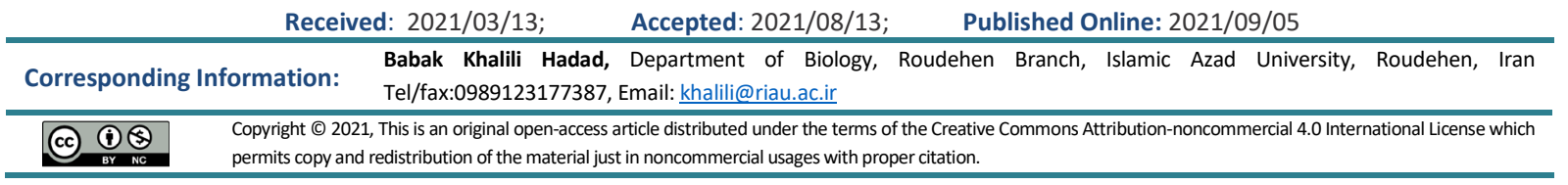

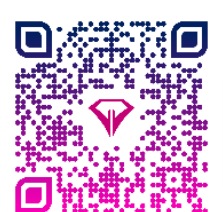

Use your device to scan and read the article online

Download citation: $\underline{B i b T e X}$ | RIS | EndNote | Medlars | ProCite | Reference Manager | RefWorks
Send citation to:
Mendeley
2 Zotero
Hi RefWorks

\section{Introduction}

The skin is the largest organ and the outer covering of the body of living organisms. Any damage such as wounding to this protective organ exposes the living organism to severe risks. Wounding activates the healing process, which includes different phases regulated by multiple growth factors and cytokines released from the wound site $(1,2)$. Various treatment methods have been proposed to treat wounds, including treatment with natural compounds or chemical drugs. However, the investigation and identification of probiotic bacteria have directed the attention of scientific forums toward probiotic therapy.

Probiotic is derived from the Latin preposition "pro", meaning for, and the Greek word "biotic", meaning life (3). This term refers to living organisms with health effects on the host body if consumed in sufficient quantities. Lilly and Stillwell first used the term probiotic in 1965, but Élie Metchnikoff, a Russian immunologist, studied the therapeutic effects of bacteria in his book, 'The Prolongation of Life' in 1907 (4). Since then, extensive research has been 
conducted on the therapeutic effects and function of probiotics. In vitro and in vivo experiments in humans and animal models have shown that probiotics can regulate the immune system in infectious, allergic, and inflammatory conditions. The most important and common probiotics belong to the genera Lactobacillus and Bifidobacterium. Valdez et al. pointed to the effective use of probiotic lactobacilli to treat gastrointestinal disorders, indicating their ability to secrete acids, bacteriocins, and other by-products that can neutralize infections resulting from pathogens (5). Satish et al. referred to the anti-pathogenic effects of probiotic bacteria previously described by other researchers and stated that their study was the first characterization of probiotic therapy, consistent with reduced scarring (6). A study by Lolou et al. at the University of Newcastle showed that the use of Lactobacillus and Bifidobacterium could reduce skin inflammation and affect the treatment of atopic dermatitis and allergic contact dermatitis (7). Another study by Walaa Mohammedsaeed (2015) at the University of Manchester investigated the therapeutic effect of probiotic Lactobacillus rhamnosus on skin wounds through in vivo cell culture and in vitro skin culture. Lactobacillus rhamnosus stimulated the reepithelialization process in both models by activating cell proliferation and migration. According to the results of this study, the therapeutic effect of Lactobacillus rhamnosus on cell migration and keratinocyte proliferation may lead to upregulation of cxcl2/cxcr2 expression. These findings suggest that the $\mathrm{cxcl} 2$ gene contributes significantly to the wound healing process by stimulating keratinocyte migration, proliferation, and binding (8). Mirani et al. (2017) developed a multifunctional dressing for wound management in their study at Victoria University. This engineered hydrogel-based dressing called GelDerm kept the wound site moist and prevented the growth of pathogenic microorganisms (9).

Although the therapeutic effects of probiotics, particularly Lactobacillus, on gastric ulcers and skin wounds have been studied at the national and international levels, little research has been conducted on the effect of Bifidobacterium spp., which has both known similarities and differences with Lactobacillus spp., on the healing of skin wounds. Thus, the present study took this novel approach into account and investigated the therapeutic effect of the Bifidobacterium $b$. probiotic bacterium by the application of bacterial culture supernatant in acute wound healing in female (BALB/c) mice in the form of the novel dressing design. On the other hand, Aloe vera hydrogel was used in this dressing to keep the wound moist, alleviate pain by cooling, and control side effects such as fissures in the wound site, which cause fragility and further damage.

\section{Material and Methods}

\subsection{Chemicals and Reagents}

All the chemical reagents for preparing hydrogel and MRS (de Man, Rogosa, and Sharpe) culture to prepare supernatant are purchased from (Merck kGaA, Darmstadt, Germany). Ketamine and Xylazine (Alfasan Diergeneesmiddelen B.V, Netherland) were used to anesthetize mice. Live culture of Bifidobacterium $b$. (PTCC: 1644) was obtained from the Iranian Research Organization for Science and Technology (IROST), Tehran, Iran, in 2020.

\subsection{Preparation of Bifidobacterium b.}

\section{Supernatant}

Live culture of B. bifidum was plated in MRS broth $(\mathrm{pH}$ value 5.5), co-cultured at $37^{\circ} \mathrm{C}$ for $72 \mathrm{~h}$, under microaerophilic condition to reach microbial suspension $\left(3 \times 10^{8} \mathrm{CFU} \cdot \mathrm{mL}^{-1}\right)$ (10). Prepared suspension incubated at $4^{\circ} \mathrm{C}$ for $15 \mathrm{~min}$, and centrifuged at $1700 \times \mathrm{g}$. The supernatant was separated and filtered through a $0.2 \mu \mathrm{m}$ microfilter.

\subsection{Preparation of Hydrogel}

$0.1 \mathrm{gr}$ of Methyl Paraben and $100 \mathrm{~mL}$ of doubledistilled water with Aloe Vera gel were placed in Bainmarie at $50-60^{\circ} \mathrm{C}$ for $20-30 \mathrm{~min}$. The mixture was passed through the Whatman Filter Paper. $100 \mathrm{~mL}$ of water and $10 \mathrm{gr}$ of Carbopol were added, and the mixture was completely homogeneous. Finally, 4 gr of Glycerol was added and stored in the refrigerator for $24 \mathrm{~h}$.

2.4 Induction of Skin Wound on Mice and treatment with drug formulation

In this study, 44 Female BALB/c mice (6-8 week-old) weighting (approximately 18-23 gr) were obtained from the Pasteur Institute, Tehran, Iran. In order to adapt to the new environment, mice were housed for one week in the Animal laboratory of the Islamic Azad University, Central Tehran Branch, in separate and sterile cages. During the study, the temperature was $22 \pm 4^{\circ} \mathrm{C}, 12 \mathrm{~h}$ day and night cycle with full access to water and food were considered. All the principles of keeping laboratory animals were in accordance with the ethical guidelines of the university (IR.IAU.SRB.REC.1398.118). These animals were then randomly divided into experimental, sham, controls, and healthy groups. To induce injury, mice were anesthetized by intraperitoneal injection of the Ketamine $10 \mathrm{mg} / \mathrm{kg}$ and Xylazine $20 \mathrm{mg} / \mathrm{kg}$.

After shaving the dorsal surface, $8 \mathrm{~mm}$ acute wound was made using biopsy punches (Kai, Japan) (11). Then the whole skin injury site was excised, and the surgery day was considered as the 0 day. Through the phases, the ethical principles were respected and prevented from any physical harm. Mice were divided into five groups considered as experimental 1, experimental 2, sham, negative and positive controls. There were five 
mice in experimental 1 and 2, positive and negative control groups, and there were three mice in the sham group. Also, three mice were grouped as the healthy group. Every $48 \mathrm{~h}$ treatments were administrated for each mouse; $50 \mathrm{ml}$ of $72 \mathrm{~h}$ bacterial culture supernatant with $8 \mathrm{~mL}$ of hydrogel prepared as a drug base for experimental group1 and Eucerin for experimental 2 were placed on sterile gas and dressed. The negative control group was untreated. Positive control only dressed with Eucerin. In the sham group, hydrogel was used for dressing. After all, wound sizes were measured by caliper every 48 hours (12).

\subsection{Histological Studies}

Mice were euthanized on days 7 and 14; biopsy sites were excised, fixed in $10 \%$ formalin, and processed for routine histology. The section was stained with haematoxylin - eosin (measuring the wound diameter and counting the blood vessels) photographed with a bright-field microscope (Olympus, Tokyo, Japan) (1315).

\subsection{Statistical Analysis}

The results were analyzed using SPSS software version 26 (SPSS Inc., Chicago, IL., USA) by one-way
(ANOVA) and (Tukey) test. Values were given as the mean standard error of the mean. The $P$-values are shown as $P$-value $<0.05$.

\section{Results}

\section{Histological Studies}

3.1 Measuring Wound Diameter in the Study Groups As can be seen in figure 1, wound diameters in all groups showed a significant decrease on days 7 and 14 of the study compared to day $0(8000 \mu \mathrm{m})$. On the $7^{\text {th }}$ day of this study, wound diameter was found in the negative control group $4111.10 \pm 82.72$ and in the positive control and sham were found $3306.48 \pm 34.79$ and $3024.77 \pm 60.70 \mu \mathrm{m}$, respectively. The wound diameters in experimental groups 1 and 2, on day $7^{\text {th }}$ were measured $870.67 \pm 75.30$ and $2132.99 \pm 78.57$, respectively. The results of the $14^{\text {th }}$ day were obtained from the negative, positive and sham equivalent to $2159.97 \pm 146.09$, $1373.69 \pm 85.53$, and 935.50 \pm 72.17 . In the case of experimental groups, wound diameters were measured $* 124.23 \pm 56.2$ and $* 415.08 \pm 33.04$ $(P<0.05)$.

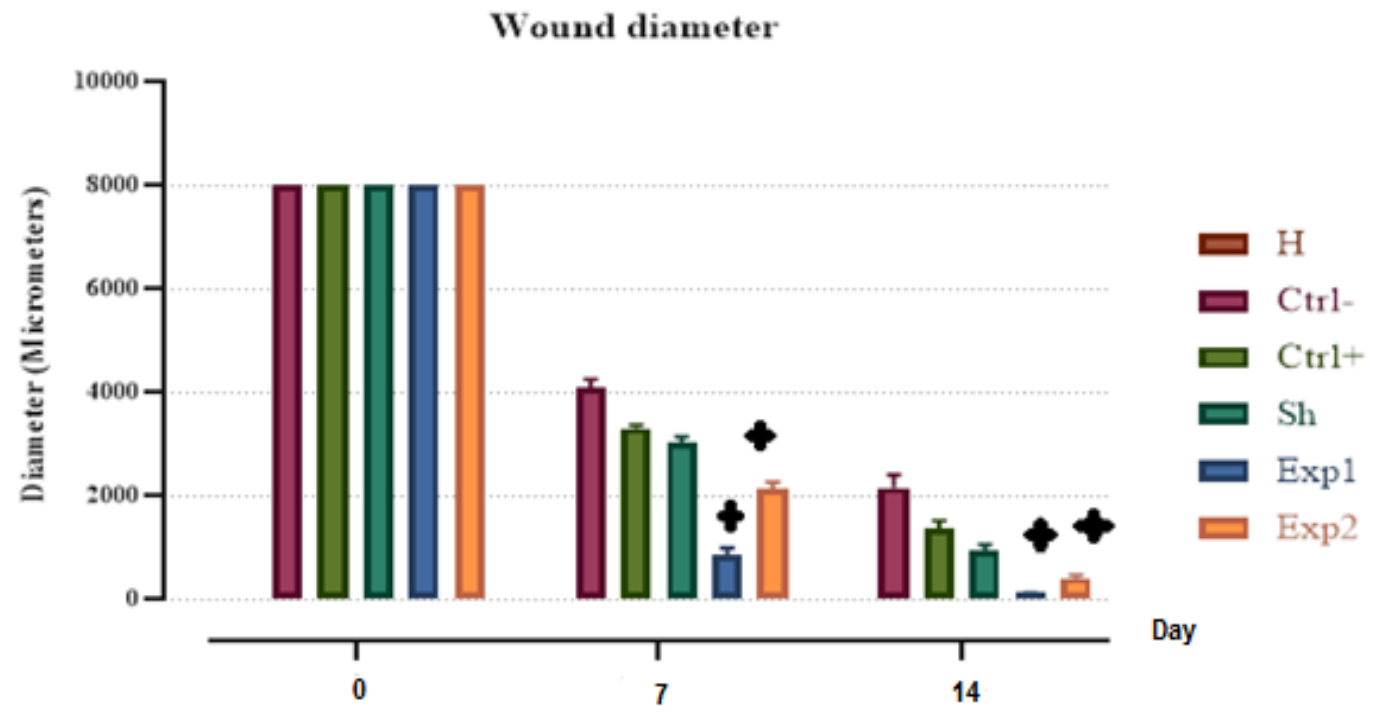

Figure 1. Wound diameter changes in different groups during the treatment period. Results are expressed as mean \pm standard error of the mean. The $P$ - values were considered significant at $* P<0.05$ levels. 


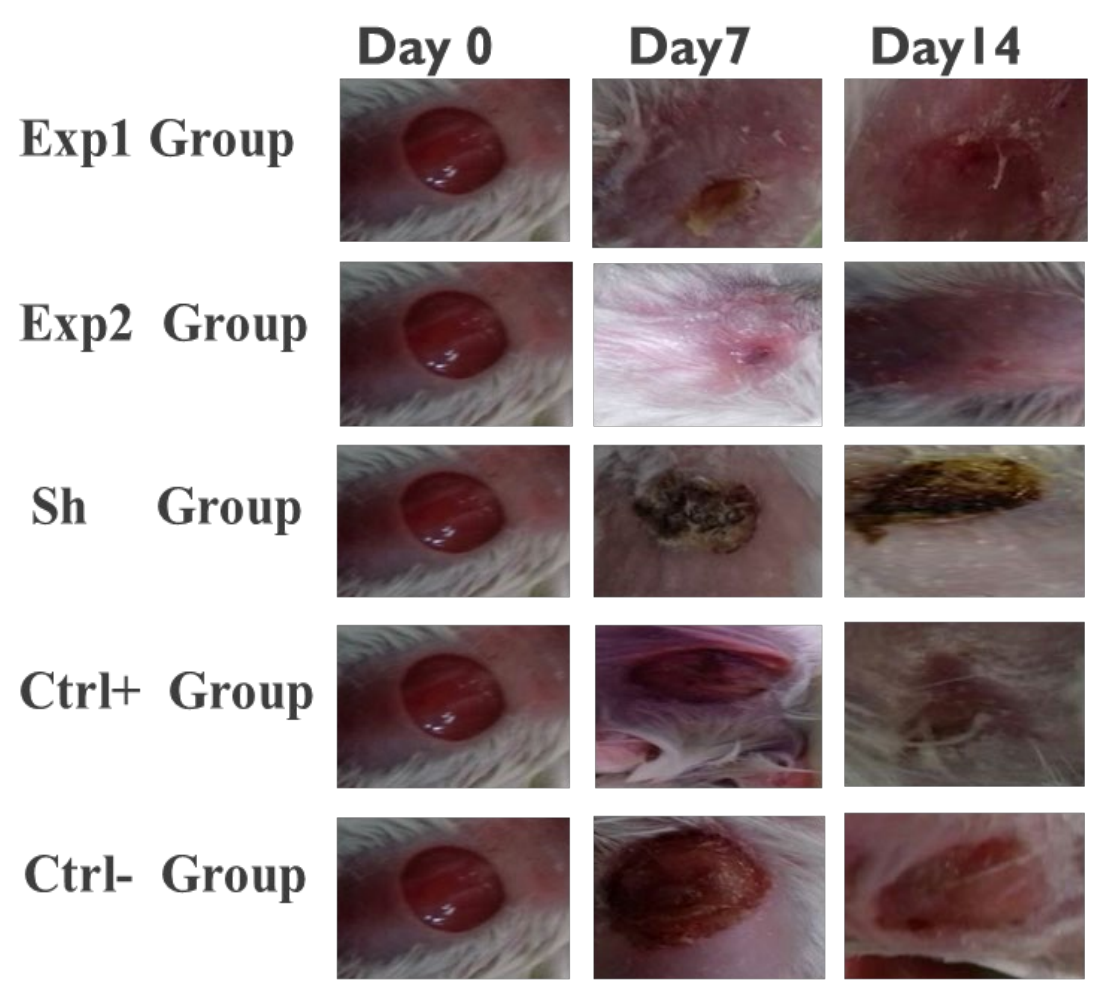

Figure 2. Macroscopic images of wound samples under different treatments at days 0,7 , and 14 of the study.

\subsection{Counting blood vessels (Angiogenesis indicator)}

Figure 3 shows the rate of angiogenesis indicator (in $500 \mathrm{\mu m}^{2}$ ) during the wound healing process in different groups on the study days. The obtained results in this study show that the rate of angiogenesis on the $7^{\text {th }}$ day of the study was $2.41 \pm 0.08,4.25 \pm 0.72$, and $9.33 \pm 0.30$ micrometers in the negative control, positive control, and sham groups, respectively. On $14^{\text {th }}$ day of study, they changed to $4.75 \pm 0.90$, $5.83 \pm 0.36$, and $6.91 \pm 0.36$, respectively. In case of experimental groups 1 and 2, compared to 0 day, the rate of angiogenesis on the $7^{\text {th }}$ day of the study increased from $11.33 \pm 0.46$ to $14.33 \pm 0.33$; Also angiogenesis decreased to $11.50 \pm 0.38$ and $9.08 \pm 0.33$ on $14^{\text {th }}$ day of the study $(P<0.05)$.

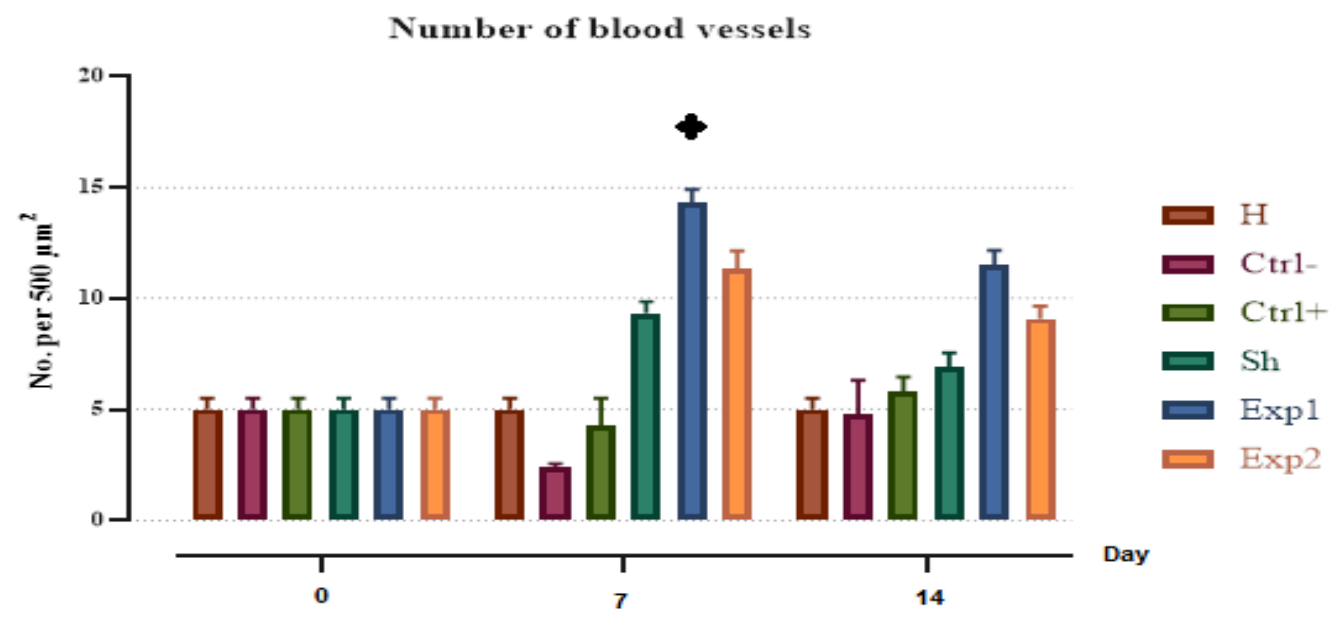

Figure 3. Changes in the number of blood vessels in different groups during the treatment process. The highest number of blood vessels belonged to experimental group1. Results are expressed as mean \pm standard error of the mean. The $\mathrm{P}$ - values were considered significant at $* P<0.05$ levels. 
Day 0
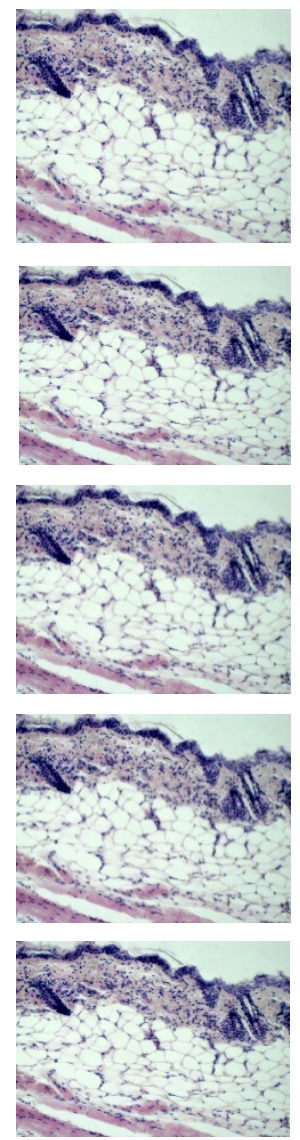

Day 7
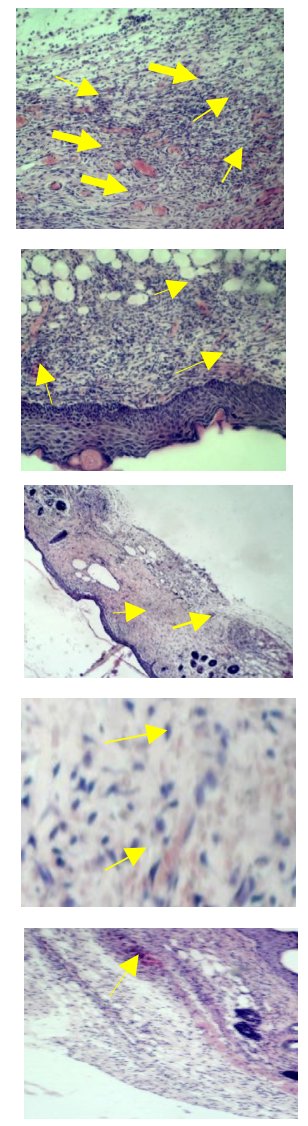

Day 14

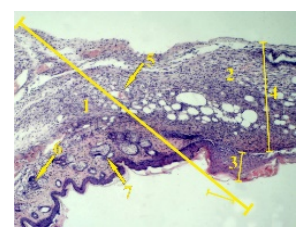

Exp1 Group

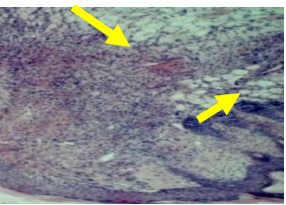

Exp2 Group

Sh Group

Ctrl+ Group

Ctrl- Group

Figure (4) Microscopic images of the wound section. In the study groups during 14 days of study. Tissue samples were stained with hematoxylin- eosin and tissue images were photographed with Olympus microscope on days 0,7 , and 14 of the study. Yellow arrows in groups indicate blood vessels. The highest number of blood vessels was seen on day 7 in the experimental group1. A section of different parts of skin belongs to experimental group 1, numbered on the 14 day of study is in the following figure: 1. Healthy skin, 2. Wound location, 3. Epidermis, 4. Dermis, 5. Blood vessel, 6. Hair follicle, 7. Sebaceous glands

\section{Discussion}

This study aimed to investigate the effect of probiotic bacteria on the duration of acute wound healing. Hence, an experiment was designed to determine the most effective indicator of acute wound healing by measuring various qualitative indicators according to the known mechanisms of wound healing. Regarding numerous studies previously conducted on lactobacilli in healing gastrointestinal ulcers and scarce research on the role of bifidobacteria in healing skin wounds, the study focused on the potential role of Bifidobacterium $b$. probiotic bacteria to reduce the duration of the treatment. Previous studies have employed probiotic bacteria in various forms, such as extracts and cell lysates $(8,16)$. Given the possible toxic and fatal effects of living probiotic bacteria in the blood, the topical application of supernatant resulting from bacterial cell culturing could be more appropriate in terms of stability at room temperature compared to live cells, making it suitable for in vitro and in vivo studies $(8,17)$. This experiment would rather use bacterial culture supernatant instead of living bacteria. A study by Walaa Mohammedsaeed (2015) at the University of Manchester also showed that lysed Lactobacillus rhamnosus G.G did not have harmful effects as the live bacteria. Moreover, lysed probiotics are more cost-effective for the treatment of skin infections, as there is no need to preserve living bacteria (8). 
The in vitro experiment of the current study examined 44 female BALB/c mice in six groups. The results of this experiment were analyzed concerning the indicators of wound diameter and number of blood vessels, assessed by macroscopic studies and calculated by histological studies along with statistical analysis, respectively. Reduction in the wound size and depth is a determining indicator during the healing period. This important repair response begins in the proliferative phase with the migration of fibroblasts and myofibroblasts to the wound. Proliferation and production of matrix and procollagen proteins 1 and 3 at the end of the first post-injury week and extracellular matrix density later support cell migration and the repair process. Wound contraction occurs with the removal of fibroblasts. In the remodeling phase, collagen is regenerated, wounds are completely consolidated, and collagen fibers are intertwined to reduce the scar thickness $(18,19)$.

The present study showed that the application of the probiotic Bifidobacterium $b$. led to the reduction of treatment duration. The data obtained in accordance with cellular and molecular mechanisms of wound healing showed the most significant decrease in the indicator of wound diameter in the experimental groups compared to sham, positive, and negative control groups $(P<0.05)$ (Figure 1$)$. A comparison of the experimental groups 1 and 2 indicated more and faster healing response of wound contraction in experimental group $1(P<0.05)$ with the smaller wound size on the seventh day of the treatment. The probiotic agent seemed to shorten the duration of the inflammatory phase, leading to faster onset of fibroblasts migration and proliferation phase. Previous studies have mentioned the role of Toll-like receptors (TLRs) expression in neutrophils, fibroblasts, monocytes, and macrophages in the repair process. Researchers believe that these may be due to probiotic function through TLRs that play a key role in the innate immune system (20).

Angiogenesis and vasculogenesis play a crucial role in wound healing. Neovascularization or angiogenesis is involved in the growth of new capillaries to form granular tissue. Three to five days after tissue damage, the capillaries become visible as granular tissue forms on the wound site, functioning as a network for blood vessel proliferation, fibroblast migration, and new collagen $(21,22)$. Any factor that can accelerate the formation of blood vessels in the wound and establish blood circulation to the tissue area helps to stimulate the wound healing process and prevent the wound deepening. In this study, the culture supernatant of the Bifidobacterium $b$. showed the potential to increase angiogenesis in the experimental groups. Hence, a comparison of the experimental group 1 and the sham group showed that despite the common hydrogel composition in both dressings and the antibacterial and antiviral properties of the constituents of hydrogels $(23,24)$ in preventing microbial growth and reducing inflammation and pain $(8,25)$, the experimental group 1 has a better performance in the process of wound healing and angiogenesis because of the probiotic agent.

As the results show, experimental groups 1 and 2 had the highest angiogenesis on the $7^{\text {th }}$ day, respectively, compared to the control groups. This result suggests that the increase in angiogenesis is due to the probiotic bacterium Bifidobacterium $b$. function. It is well known that the rate of angiogenesis in granular tissue reaches its peak around the $7^{\text {th }}$ day of injury, after which the blood vessels are gradually destroyed. In this experiment, the highest rate of angiogenesis occurred on the $7^{\text {th }}$ day of treatments in experimental group 1 , which is consistent with previous studies $(P<0.05)$. Given the ascending trend of angiogenesis until the $7^{\text {th }}$ day of the injury, such as what happens in the proliferative phase, and its gradual decline, the quantitative index of blood vessels follows a decreasing trend from the $7^{\text {th }}$ to $14^{\text {th }}$ day of the study in the experimental groups, which is consistent with re-epithelialization phase (Figure 2) $(P<0.05)$. The use of bacterial culture supernatant also seems to act as a stimulant and increase angiogenesis (Figure 2). Previous studies have shown that it is possible to improve angiogenesis by activated macrophages and epidermal tissue. Until recently, acid or basal fibroblast growth factors seemed to be responsible for such activities, but it is now clear that other molecules such as vascular endothelial growth factor (VEGF), angiogenin, and angiopoietin are involved in angiogenic activities (19). Keratinocytes produce VEGF from the early to the final stages of wound healing. Activated fibroblasts, mast cells, and macrophages express VEGF in injured skin. In fact, myeloid cells (monocytes and macrophages) are the major source of VEGF in the post-injury stages. Studies have also shown the effects of both keratinocytederived and myeloid cell-derived VEGF on wound healing (26). It also seems that the tissue stimulates macrophages to secrete VEGF in the face of hypoxia (8). Studies on mouse models have shown that a lack of VEGF in myeloid cells and keratinocytes delays wound contraction, decreases blood vessel density, and reduces granular tissue formation. Low levels of oxygen in injured skin activate the Hypoxia Inducible Factor, leading to VEGF gene transcription (26). A study in mice showed that probiotics increased the expression of VEGF and TGF- $\beta$ (27).

As shown by Halper et al., Lactobacillus extract stimulates the production of TNF- $\alpha$ and angiogenesis in the inflammatory phase of tissue repair as inflammatory cells such as macrophages, lymphocytes, 
and plasma cells support pro-inflammatory processes (28).

According to the intragroup comparison of experimental groups 1 and 2 in the present study, Eucerin did not contribute to wound healing and the increasing number of blood vessels. There are no reports on the antibacterial or antiviral properties of Eucerin, which softens and relieves dry skin. Therefore, a careful comparison of the groups showed that although the bacterial culture supernatant coupled with Eucerin affected the wound healing process, the use of this liquid with hydrogel had the greatest effect on wound healing and angiogenesis $(P<0.05)$. No infection was observed in the experimental groups of the present study as probiotics prevented wound infection by antimicrobial mechanisms, including secretion of antimicrobial peptides, inhibition of bacterial invasion, and inhibition of pathogenic bacteria adhesion to epithelial cells (29). On the other hand, the intra-group comparisons of the control groups also showed no significant differences in the wound diameter and the number of blood vessels in the group receiving no treatment (negative control) and the group receiving Eucerin dressing (positive control).

In general, as the results of this study showed, increased angiogenesis and decreased wound diameter was consistent with previous studies $(5,6)$, while the probiotic bacterium Bifidobacterium $b$. reduced the duration of treatment. It is well known that time plays a crucial role in reducing or increasing the outcomes of wounding $(30,31)$. Given the significant decrease in the wound diameter and increase in angiogenesis of the experimental groups on the 7th day, it seems that shorter phases of three, five, seven, and nine days (32) may help determine a more accurate interval for these two indicators in future studies. It is also possible to use the bacterial culture supernatant of Bifidobacterium $b$. probiotic bacterium alone and investigate its effects.

\section{References}

1. Yousef H, Alhajj M, Sharma S. Anatomy, skin (integument), epidermis. 2017.

2. Jimi S, Jaguparov A, Nurkesh A, Sultankulov B, Saparov A. Sequential delivery of cryogel released growth factors and cytokines accelerates wound healing and improves tissue regeneration. Frontiers in Bioengineering and Biotechnology. 2020;8:345 (DOI:10.3389/fbioe.2020.00345) (PMID) (PMCID)

3. Markowiak P, Śliżewska K. Effects of probiotics, prebiotics, and synbiotics on human health.

\section{Conclusion}

According to the results of the current study, the probiotic bacterium Bifidobacterium $b$. reduces wound diameter, increases angiogenesis, and decreases the duration of the treatment significantly $(P<0.05)$. This study, which is in line with research on the therapeutic effects of probiotics in scientific and academic centers of Iran and other parts of the world (8), indicates the effectiveness and usefulness of this therapeutic method. Besides, this study shows that the bacterial culture supernatant of Bifidobacterium $b$. probiotic bacterium can be an alternative and reliable treatment. Thus, it is possible to use the designed biological dressing containing bacterial culture supernatant of Bifidobacterium $b$. probiotic bacterium and Aloe vera hydrogel to treat acute wounds after further studies.

\section{Acknowledgment}

This current research article has been adapted from the dissertation of Ms. Pegah Moussavi Amin with University code number 33262. The ethical instructions were approved by the Vice-Chancellor for Research and Technology of the Islamic Azad University, East Tehran Branch. Also, thanks go to everyone who has helped us to achieve this important goal.

\section{Author Disclosure Statement}

The authors have no conflict of interest concerning this manuscript.

\section{Funding}

This article is an independent study that was conducted without organizational financial support.

\section{Conflict of Interest}

The authors declared no conflict of interest.

Nutrients. 2017;9(9):1021.

(DOI:10.3390/nu9091021) (PMID) (PMCID)

4. Zommiti M, Feuilloley MG, Connil N. Update of probiotics in human world: a nonstop source of benefactions till the end of time. Microorganisms. 2020;8(12):1907. (DOI:10.3390/microorganisms8121907) (PMID) (PMCID)

5. Plaza-Diaz J, Ruiz-Ojeda FJ, Gil-Campos M, Gil A. Mechanisms of action of probiotics. Advances in Nutrition. 2019;10(suppl_1):S49-S66. 
(DOI:10.1093/advances/nmy063)

(PMCID)

6. Satish L, Gallo PH, Johnson S, Yates CC, Kathju S. Local probiotic therapy with Lactobacillus plantarum mitigates scar formation in rabbits after burn injury and infection. Surg infections. 2017;18(2):119-27. (DOI:10.1089/sur.2016.090) (PMID) (PMCID)

7. Lolou V, Panayiotidis MI. Functional role of probiotics and prebiotics on skin health and disease. Ferment Technol. 2019;5(2):41. (DOI:10.3390/fermentation5020041)

8. Mohammedsaeed W. Characterisation of the potential of probiotics or their extracts as therapy for skin: The University of Manchester (United Kingdom); 2015.

9. Mirani B, Pagan E, Currie B, Siddiqui MA, Hosseinzadeh R, Mostafalu $P$, et al. An advanced multifunctional hydrogel-based dressing for wound monitoring and drug delivery. Adv. Healthc. 2017;6(19):1700718.

(DOI:10.1002/adhm.201700718) (PMID) (PMCID)

10. Saberian M, Delshad ES, Habibi M. The Effect of Bifidobacterium Bifidum Supernatant and Cell Mass on the Proliferation Potential of Rat Bone Marrow-Derived Stromal Cells. IJMS. 2020;45 (4):269.

11. Masson-Meyers DS, Andrade TA, Caetano GF, Guimaraes FR, Leite $M N$, Leite $S N$, et al. Experimental models and methods for cutaneous wound healing assessment. Int j Exp Pathol. 2020;101(1-2):21-37. (DOI:10.1111/iep.12346) (PMID) (PMCID)

12. Yasuda K, Ogushi M, Nakashima A, Nakano Y, Suzuki K. Accelerated wound healing on the skin using a film dressing with $\beta$-glucan paramylon. In Vivo. 2018;32(4):799-805.

(DOI:10.21873/invivo.11310) (PMID) (PMCID)

13. Hesari AK, Shahrooz R, Ahmadi A, Malekinejad H, Saboory E. Crocin prevention of anemia-induced changes in structural and functional parameters of mice testes. J. Appl. Biomed. 2015;13(3):21323. (DOI:10.1016/j.jab.2015.02.001)

14. Shahrooz R, Agh N, Jafari N, Kalantari A, Jalili R, Karimi A. Effects of fish oil replacement with vegetable oils in rainbow trout (Oncorhynchus mykiss) fingerlings diet on growth performance and foregut histology. Turkish J. Fish. Aquat Sci. 2018;18(6):825-32. (DOI:10.4194/1303-2712v18 6 09)
15. Gurina TS, Simms L. Histology, Staining. 2020.

16. Farghali H, Canová NK, Zakhari S. Hepatoprotective properties of extensively studied medicinal plant active constituents: possible common mechanisms. Pharm Biol. 2015;53(6):781-91.

(DOI:10.3109/13880209.2014.950387) (PMID)

17. Brandi J, Cheri S, Manfredi M, Di Carlo C, Vanella VV, Federici F, et al. Exploring the wound healing, anti-inflammatory, anti-pathogenic and proteomic effects of lactic acid bacteria on keratinocytes. Scientific reports. 2020;10(1):1-14. (DOI:10.1038/s41598-020-68483-4) (PMID) (PMCID)

18. DiPietro LA. Angiogenesis and wound repair: when enough is enough. J. Leukoc Biol. 2016;100(5):979-84. (DOI:10.1189/jlb.4MR0316102R) (PMID) (PMCID)

19. Tonnesen MG, Feng $X$, Clark RA, editors. Angiogenesis in wound healing. JIDSP; 2000: Elsevier. (DOI:10.1046/i.10870024.2000.00014.x) (PMID)

20. Lai Y, Di Nardo A, Nakatsuji T, Leichtle A, Yang Y, Cogen $\mathrm{AL}$, et al. Commensal bacteria regulate Toll-like receptor 3-dependent inflammation after skin injury. Nat Med. 2009;15(12):1377-82. (DOI:10.1038/nm.2062) (PMID) (MID)

21. Veith $A P$, Henderson $K$, Spencer $A$, Sligar $A D$, Baker $A B$. Therapeutic strategies for enhancing angiogenesis in wound healing. Adv Drug Deliv Rev. 2019;146:97-125. (DOI:10.1016/j.addr.2018.09.010) (PMID) (PMCID)

22. Honnegowda TM, Kumar $P$, Udupa EGP, Kumar $S$, Kumar $U$, Rao $P$. Role of angiogenesis and angiogenic factors in acute and chronic wound healing. Aesthetic Plast Surg. 2015;2:243-9. (DOI:10.4103/2347-9264.165438)

23. Teplicki E, Ma Q, Castillo DE, Zarei M, Hustad AP, Chen J, et al. The Effects of Aloe vera on Wound Healing in Cell Proliferation, Migration, and Viability. Wounds: a compendium of clinical research and practice. 2018;30(9):263-8.

24. Sánchez M, González-Burgos E, Iglesias I, GómezSerranillos MP. Pharmacological update properties of Aloe vera and its major active constituents. Molecules. 2020;25(6):1324. (DOI:10.3390/molecules25061324) (PMID) (PMCID) 
25. Darzi S, Paul K, Leitan S, Werkmeister JA, Mukherjee S. Immunobiology and Application of Aloe vera-Based Scaffolds in Tissue Engineering. Int. J. Mol. 2021;22(4):1708.

(DOI:10.3390/ijms22041708) (PMID) (PMCID)

26. Johnson KE, Wilgus TA. Vascular endothelial growth factor and angiogenesis in the regulation of cutaneous wound repair. Advs wound care. 2014;3(10):647-61.

(DOI:10.1089/wound.2013.0517) (PMID) (PMCID)

27. Lukic J, Chen V, Strahinic I, Begovic J, Lev-Tov H, Davis SC, et al. Probiotics or pro-healers: the role of beneficial bacteria in tissue repair. Wound Repair and Regen. 2017;25(6):912-22. (DOI:10.1111/wrr.12607) (PMID) (PMCID)
28. Halper J, Leshin L, Lewis S, Li W. Wound healing and angiogenic properties of supernatants from Lactobacillus cultures. Exp. Biol Med. 2003;228 (11):1329-37. (DOI:10.1177/153537020322801111) (PMID)

29. Sinha A, Sagar S, Madhumathy M, Osborne WJ. Probiotic Bacteria in Wound Healing; An In-Vivo Study. Iranian Journal of Biotechnology. 2019;17(4):e2188.

30. Nagle SM, Waheed A, Wilbraham SC. Wound Assessment. StatPearls (Internet). 2020.

31. Kuru B. The adventure of axillary treatment in early stage breast cancer. Eur. J. Breast Health. 2020;16(1):1. （DOI:10.5152/ejbh.2019.5157) (PMID) $(\underline{P M C I D})$ 


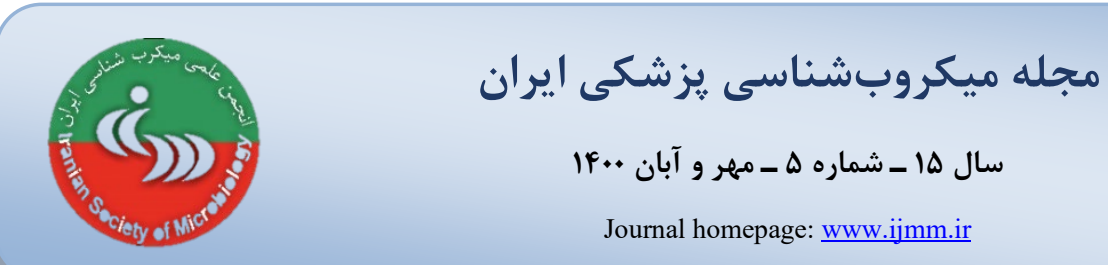

\section{بررسى تأثير مايع رويى كشت باكترى بيفيلوباكتريوم بيفيلوم بر افزايش ركزايى در ترميم زخم حاد "يخاه موسوى امين'، اكرم سادات طباطبايى بفرويى'، بابك خليلى حداد"}

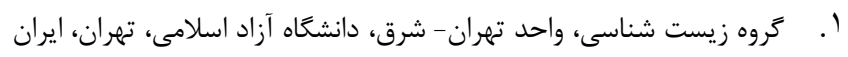

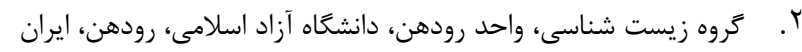

\section{جكيله}

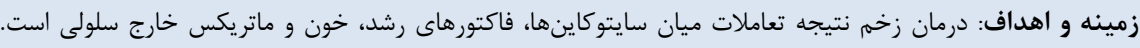

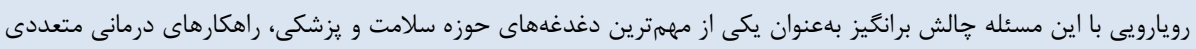

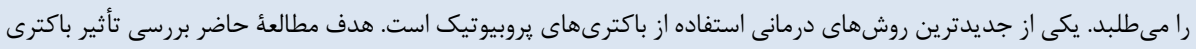

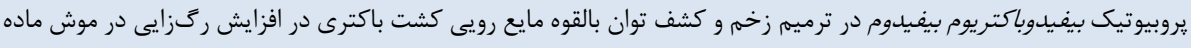

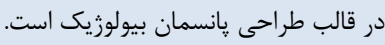

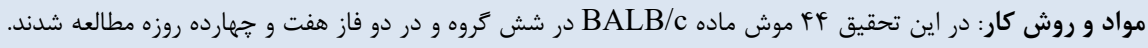

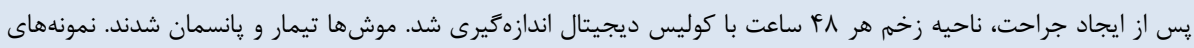

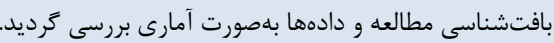

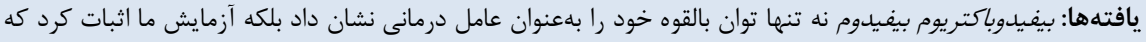

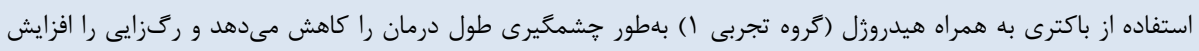

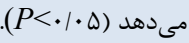

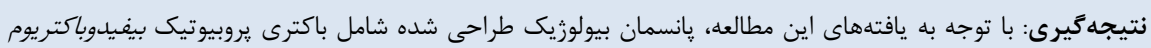

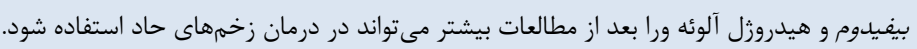

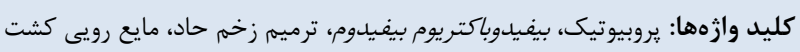

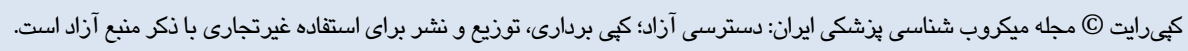

اطلاعات مقاله

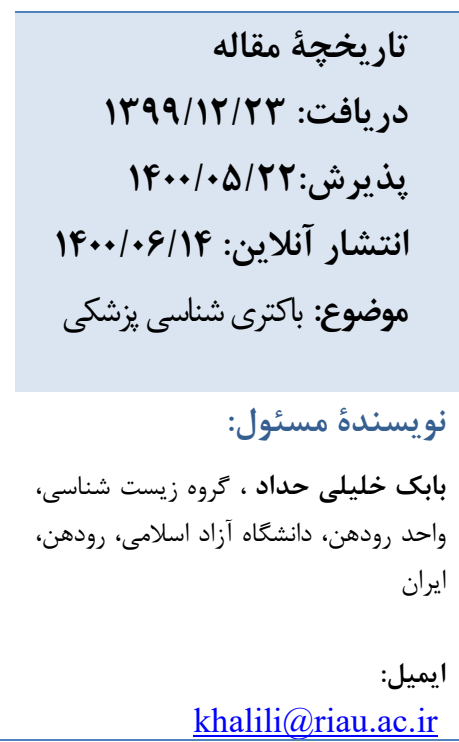

مقدمه

كار بردند اما الى مجنيكف، ايمنى شناس روس در سال V • 19 بود

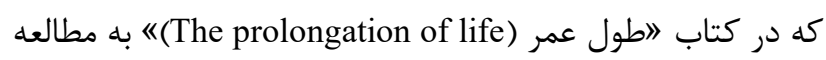
اثر درمانى باكترىها يرداخت (F). از آن هنعام تاكنون، تحقيقات دامنه دارى درباره اثرات درمانى و نحوه عمل يروبيوتيكها صورت كرفته است. آزمايشات برونتنى (in vitro) و درون (in vivo) در انسان و مدلهاى حيوانى نشان داده است كه يروبيوتيكها قادر

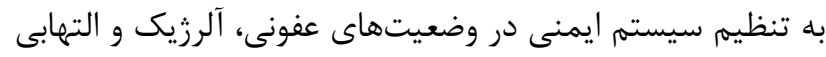
هستند. مهمترين و مرسوم ترين يروبيوتيكها به جنسهاى لهاى لاكتوباسيلوس و بيفيدوباكتريوم تعلق دارند. مطالعات والدز و

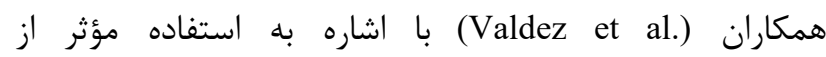
لاكتوباسيلهاى يروبيوتيك در درمان اختلالات گوارشى، توانايى

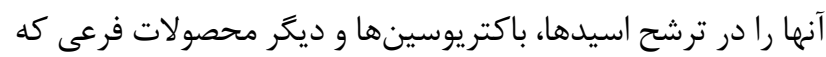

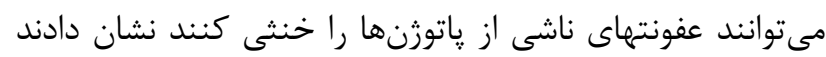
(ه). ساتيش و همكاران (Satish et al.) با اشاره به اثرات ضد پاتوزنى باكترىهاى يروبيوتيك كه ييشتر توسط ديگر محققان
يوست بزرگترين عضو بدن است كه يوشش خارجى بدن

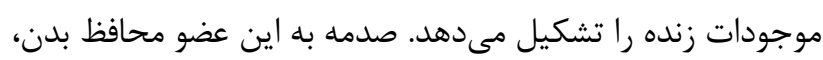

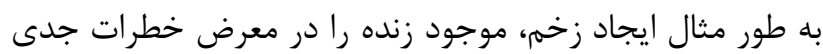

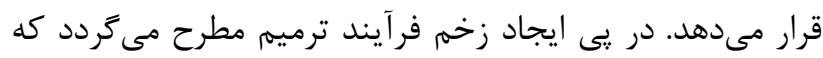
شامل فازهاى مختلفى است. اين فازها از طريق فاكتورهاى رشد

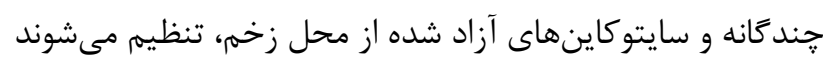
(ا، ץ). براى درمان زخم تاكنون شيوههاى متعدد درمانى از قبيل درمان با تركيبات طبيعى و يا داروهاى شيميايى مطرح بوده است.

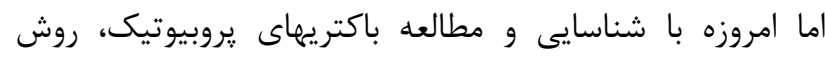
يروبيوتيك درمانى نيز در مجامع علمى مورد توجه قرار گرفته است.

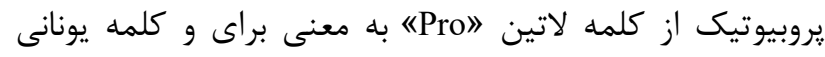

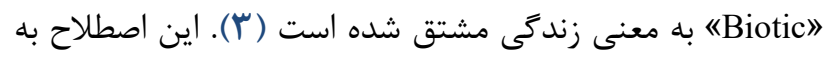
اركانيسمهاى زنده اى اطلاق مىشود كه در صورت مصرف به ميزان كافى، داراى اثرات سلامت بخش در بدن زئن ميزبان مى بـاشند.

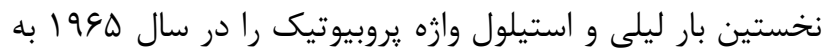




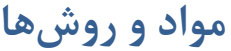

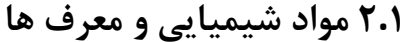

كليه مواد شيميايى براى تهيه هيدروزل و محيط كشت

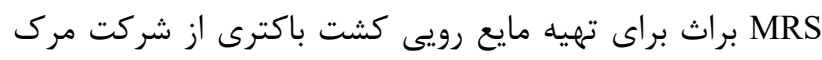
تهيه شد. داروهاى (Merck kGaA, Darmstadt, Germany)

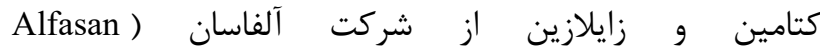
(Diergeneesmiddelen B.V ,Netherland زنده باكترى يروبيوتيك بيفيدوباكتريوم بيفيدوم مركز منطقهاى كلكسيون قارجها و باكتريهاى ايران تهيه شد.

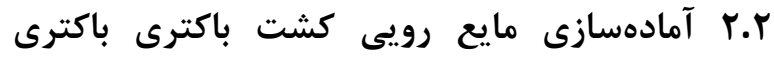 يروبيوتيك بيفيدوباكتريوم بيفيدوم} باكترى يروبيوتيك بيفيدوباكتريوم بيفيدوم در محيط كشت بيد

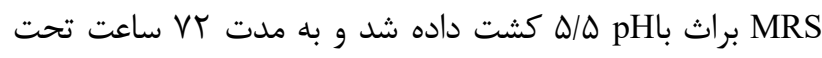

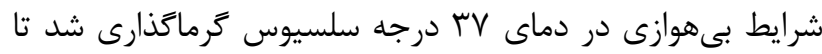

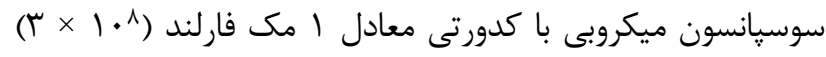

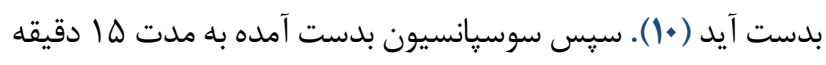

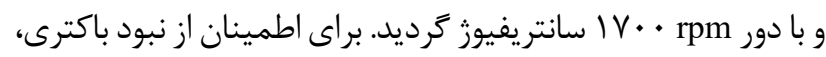

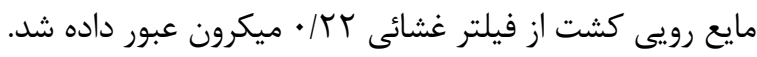

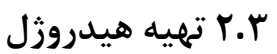

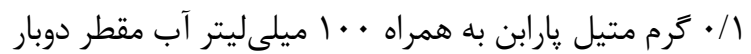

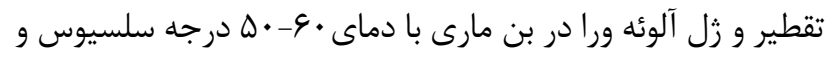

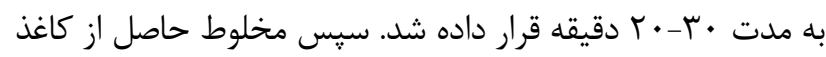

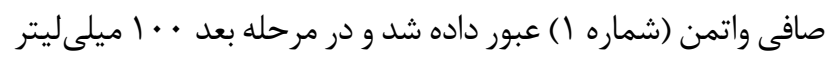
آب و • ا كرم كاربايول اضافه كرديد و تركيب به طور كامل همخن

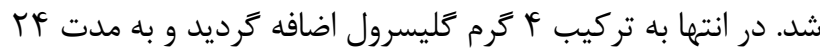
ساعت در يخجال نتخهدارى شد.

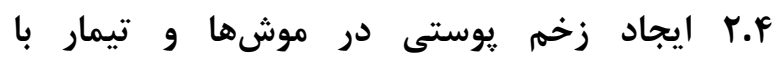

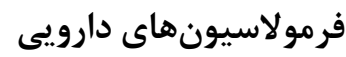

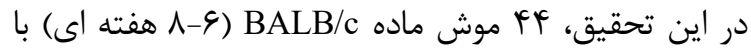

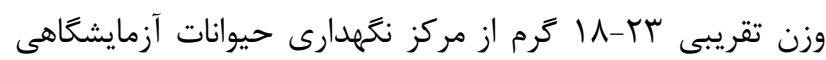

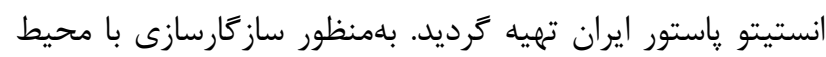

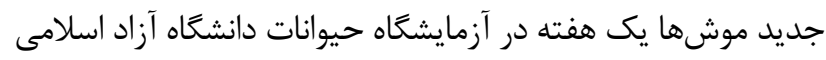

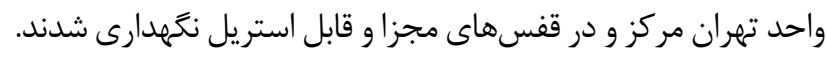

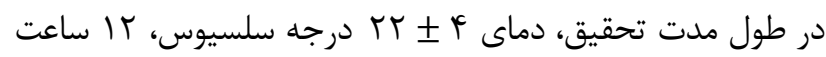

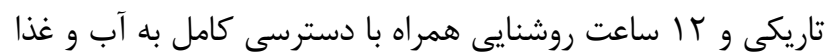

توضيح داده شده است، تصريح مى كنند كه مطالعه آنها اولين

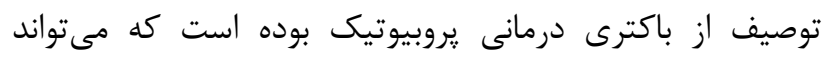

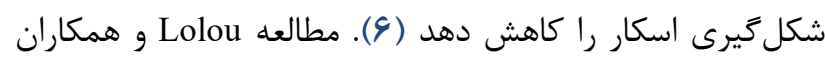

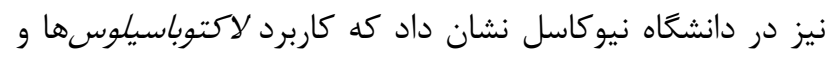
بيفيدوباكتريومها سبب كاهش التهابات يوستى مي شود و در درمان

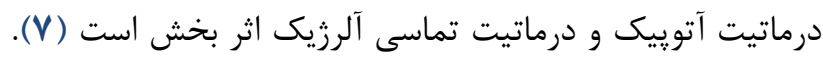

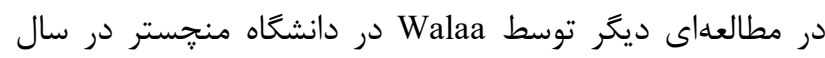

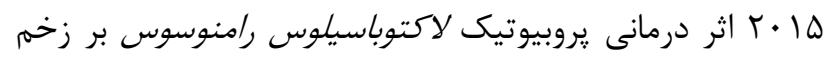

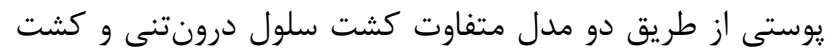

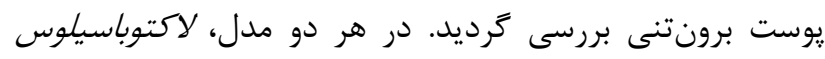

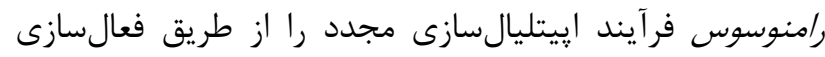
مهاجرت و تكثير سلول تحريك كرد. نتايج اين مطالعه نشان داد

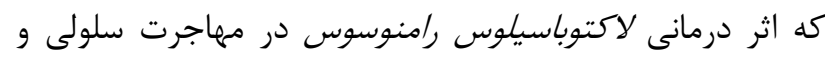

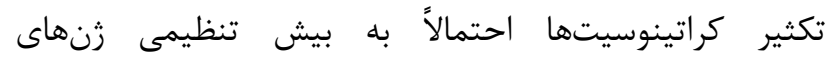
cxcl2 مي cxc12/cxcr22

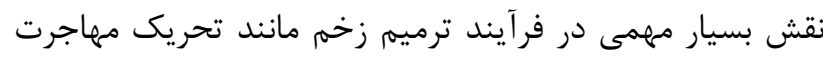

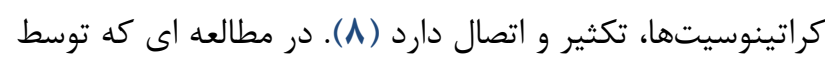
Mirani

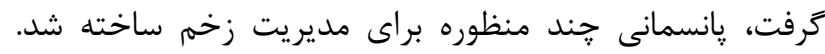

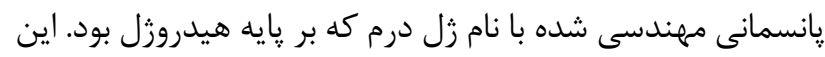

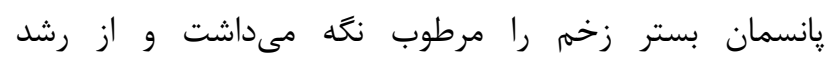

ميكروار كانيسمهاى بيماريزا جلو كيرى مىنمود (9).

با وجودى كه اثرات درمانى يروبيوتيكها و به ويزه

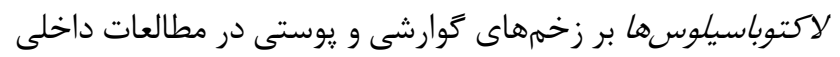

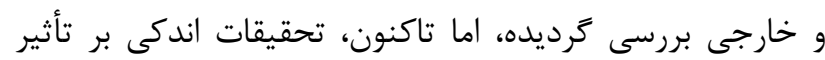

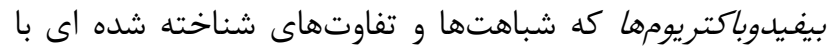
لاكتوباسيلوسها دارند، بر ترميم زخمهاى يوستى صورت ترفياهن

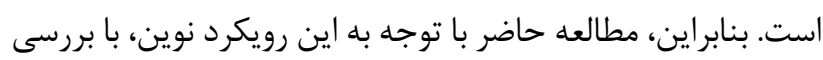

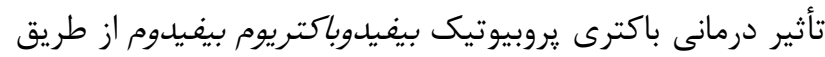
مداخله مايع رويى كشت باكترى در ترميم زخم حاد در دمان موشهاي

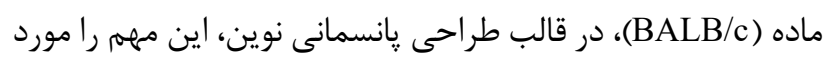

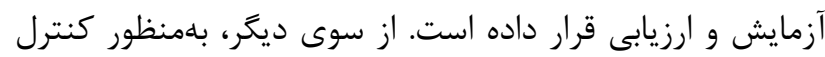

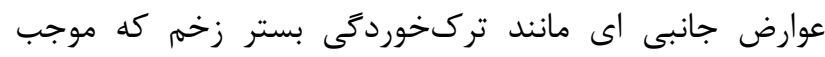

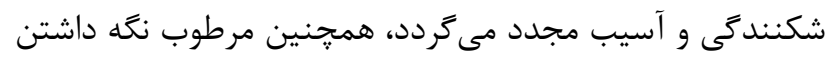

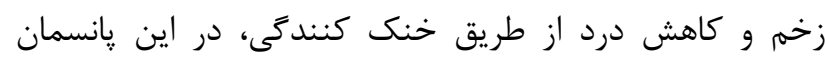
استفاده از هيدروزل آلوئه ورا در نظر كرفته شد شدي 
مقاطع بافتى، لام تهيه شد. لامها با رنخ هماتوكسيلين- ائوزين براى

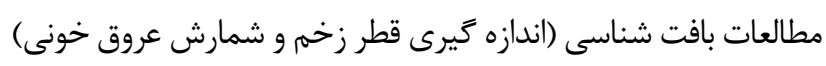

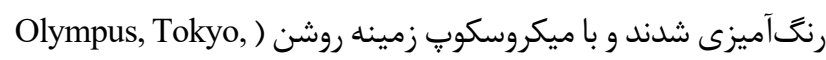

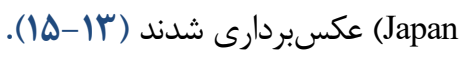

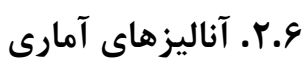

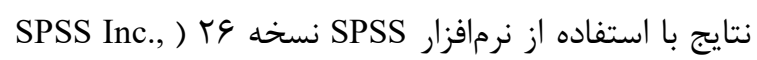
(Chicago, Ill., USA

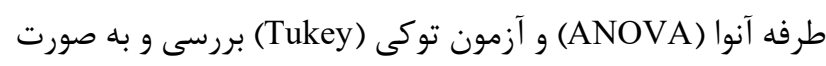

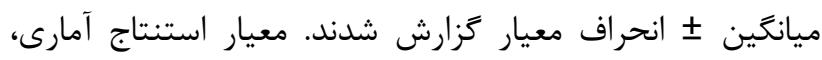
ه • • P-value

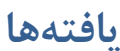

\section{مطالعات بافت شناسى}

\section{1. اندازه كَيرى قطر زخم در كروههاى مورد مطالعه}

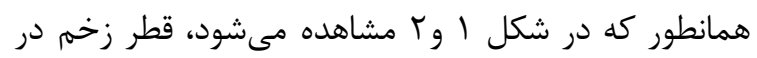

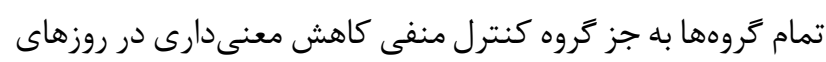

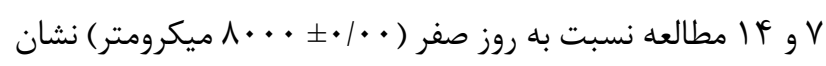

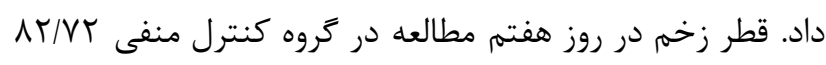

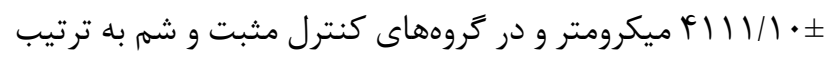

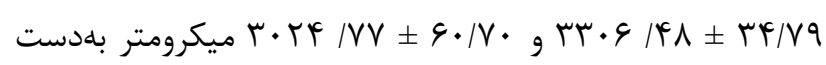

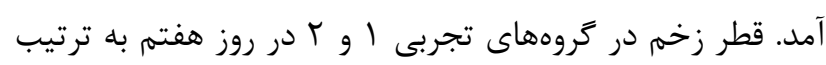

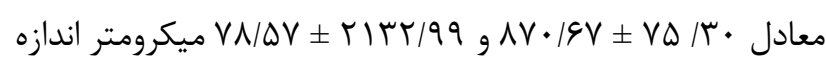
كيرى شد. نتايج روز جهاردهم در مورد گروههاى كنتر مثبت، شم به ترتيب معادل 9 كروههاى تجربى او Y بله ترتيب

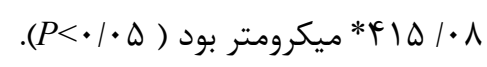

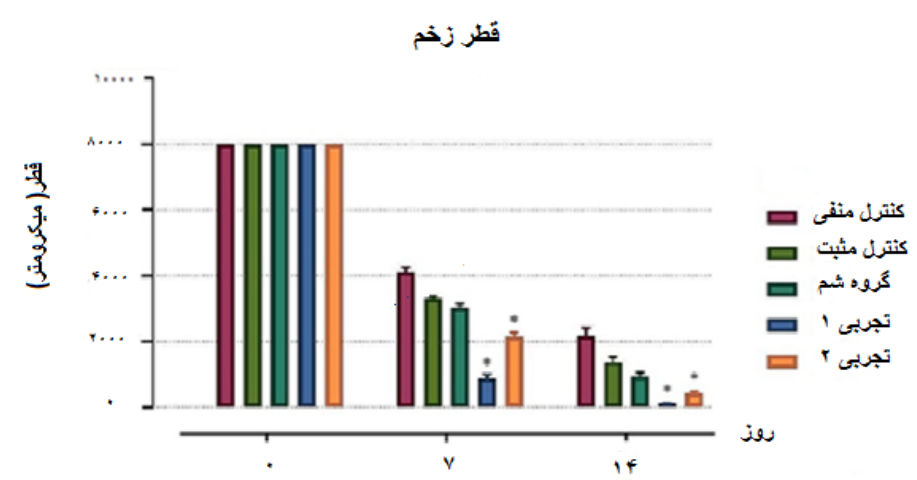

در نظر كرفته شد و تمام اصول نتخهدارى حيوانات آزمايشعاهى (كد

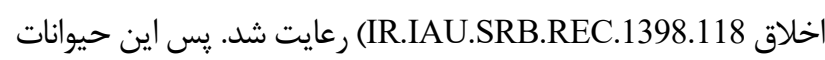

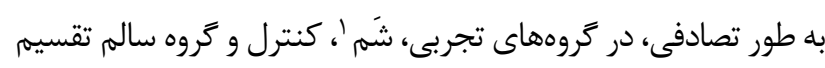

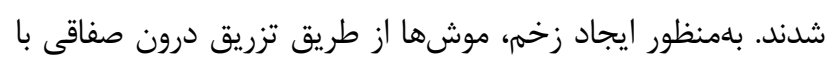

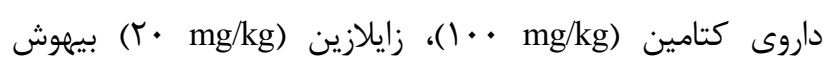

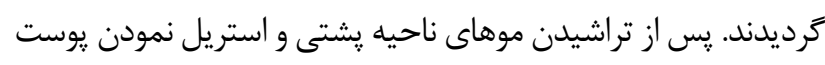

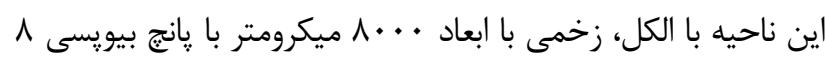

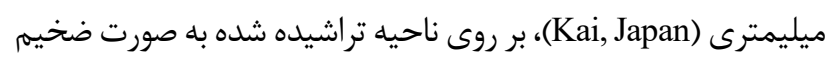
(Full -Thickness) به طور كامل جدا گرديد و روز جراحى، روز صفر در نظر ترفته شد.

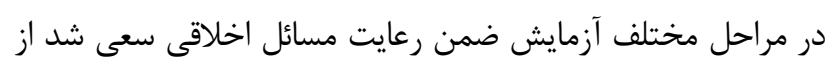

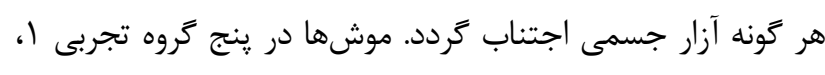

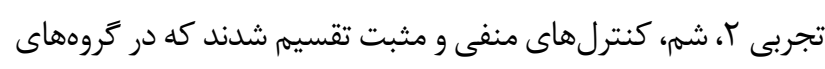

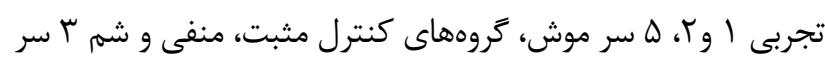

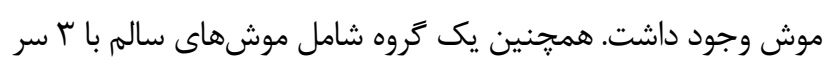

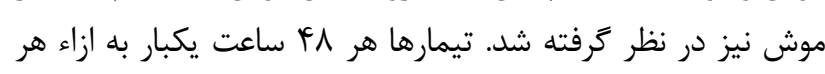

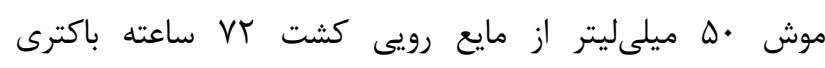

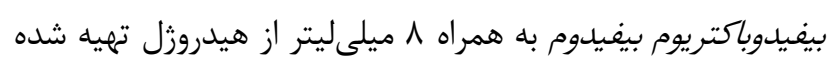

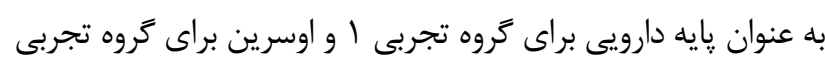

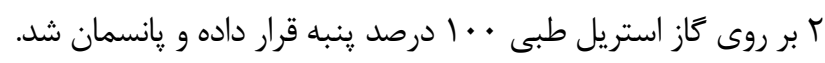

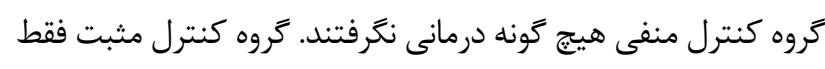

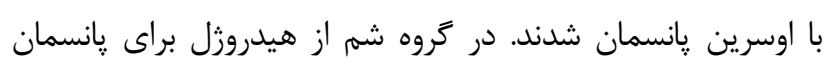

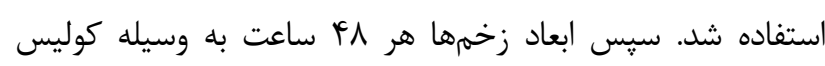

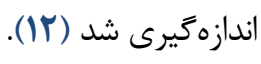

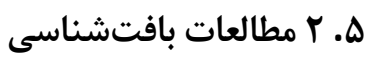

يس از كشتن موشها در روزهاى هفت و جهارده مطاس مطالعها، نمونه

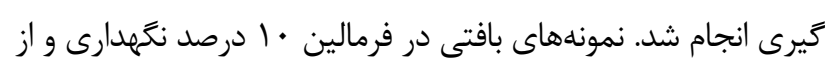




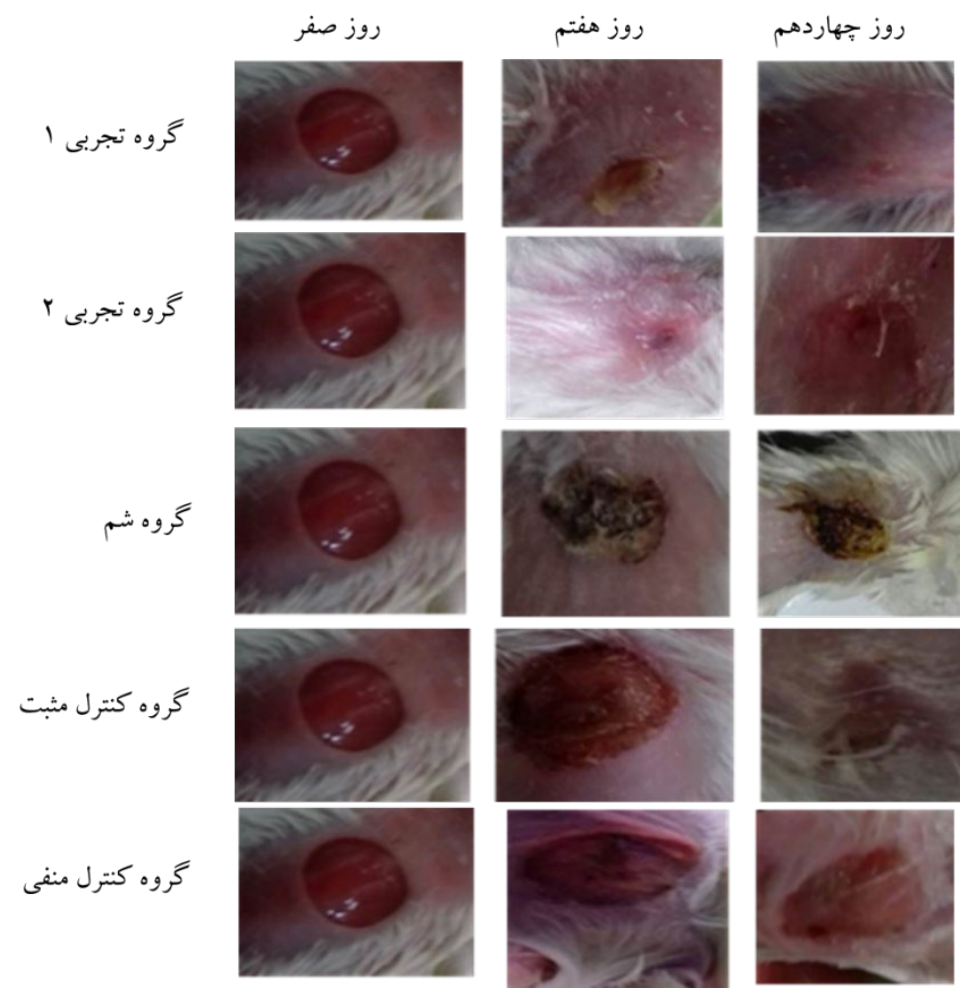

شكل r. تصاوير ماكروسكوبى نمونهاى زخم تحت تيمارهاى مختلف در روزهاى ·، V و أl مطالعاتى

جهاردهم به ترتيب به • • •

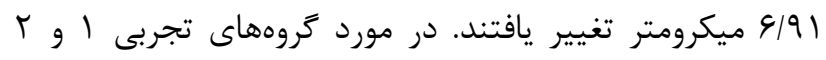

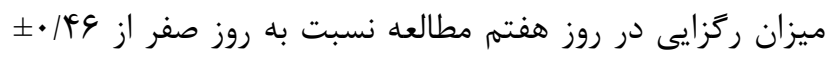

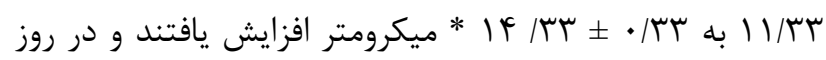

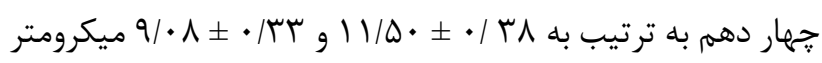

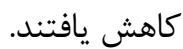

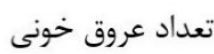

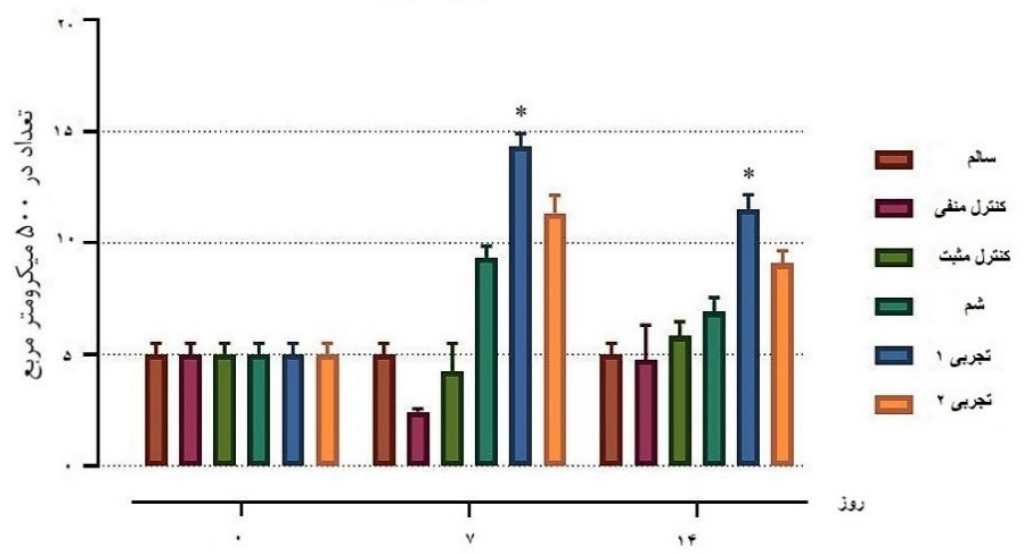

شكل r ميزان شاخص ركزايى ( در .ه ميكرومتر مربع) را

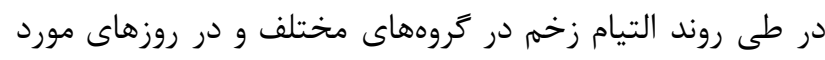

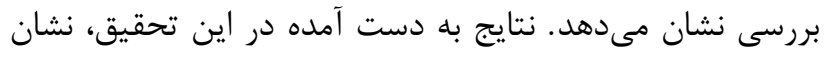

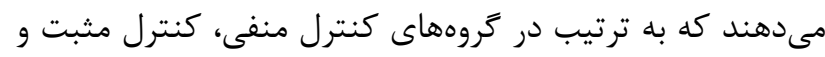

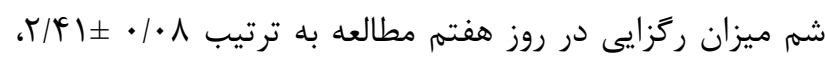

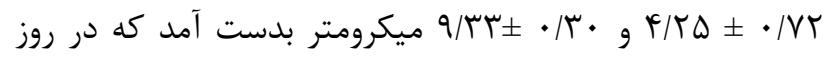

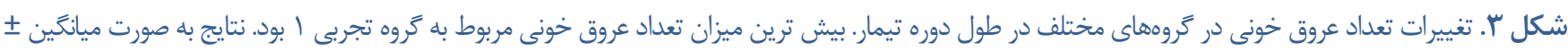

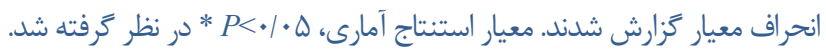



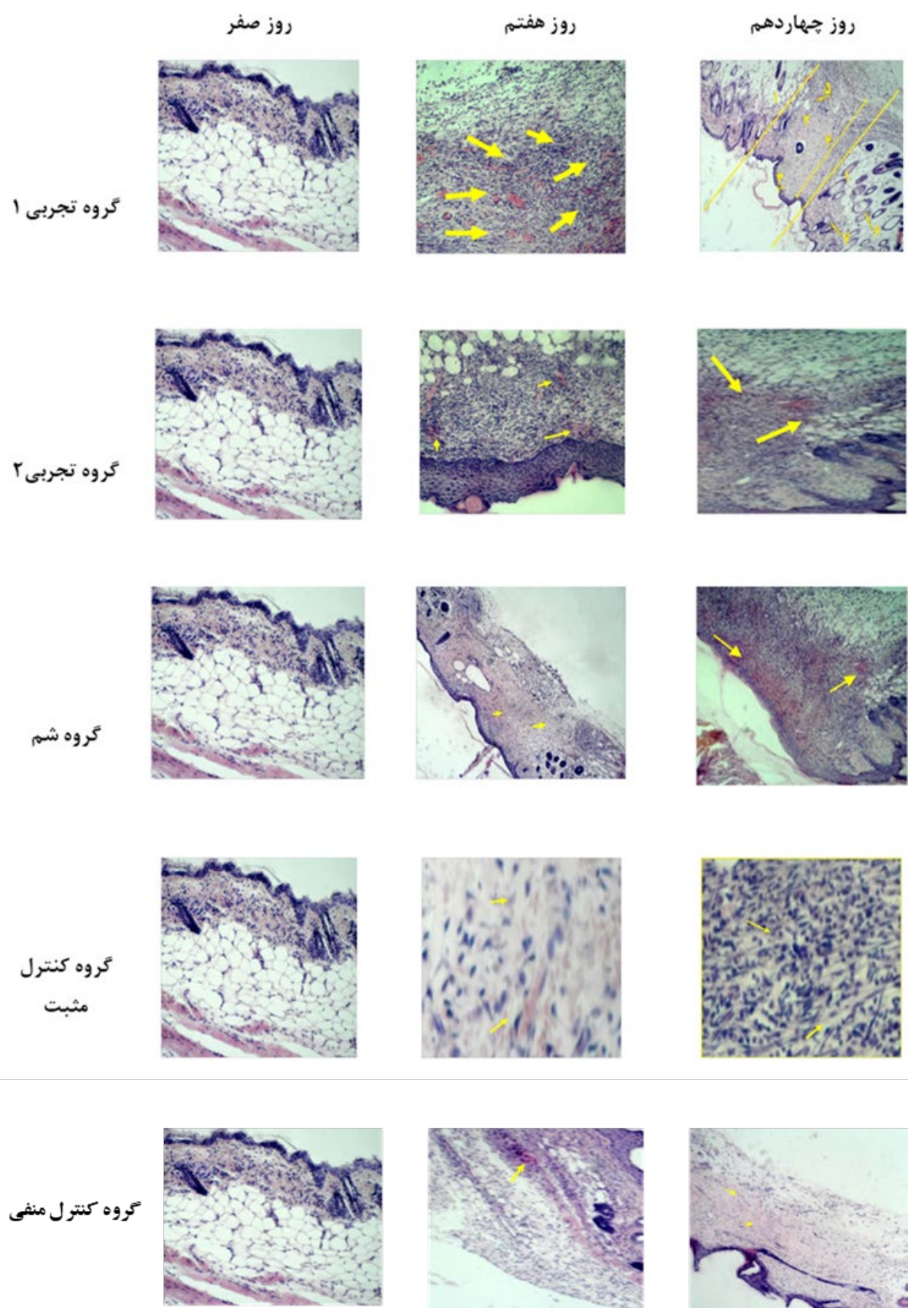

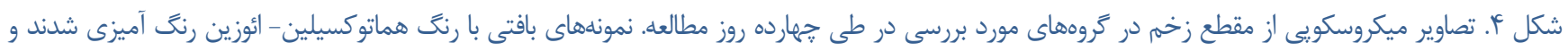

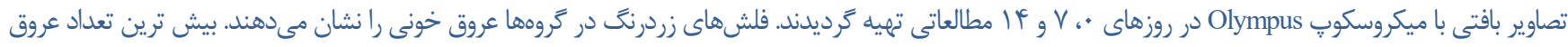

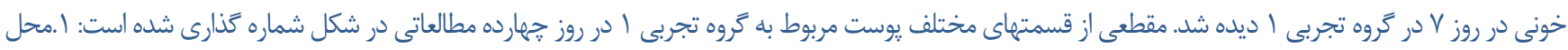

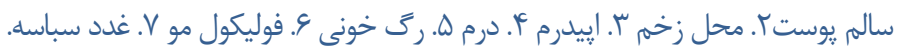

مكانيسم شناخته شده فرايند ترميم زخم حاد مشخص شود كدام

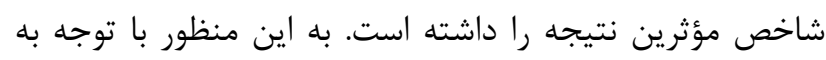

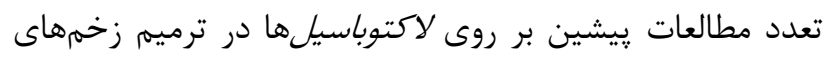

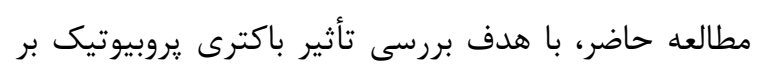

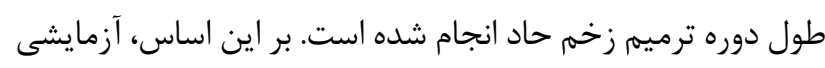

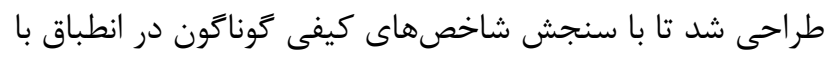


كروههاى تجربى، نسبت به گروههاى شم، كنترل مثبت و كنترل

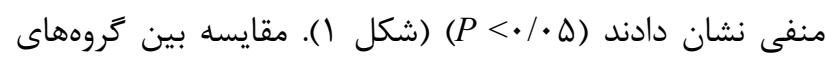

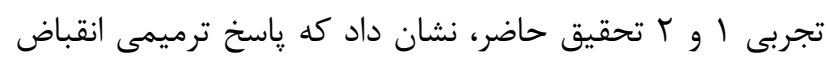

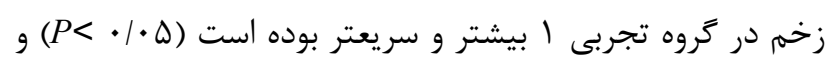

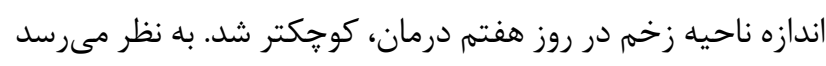

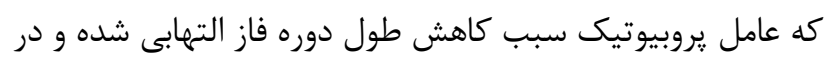

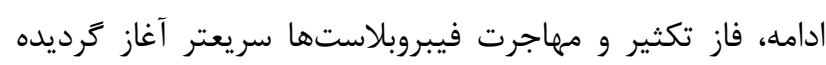

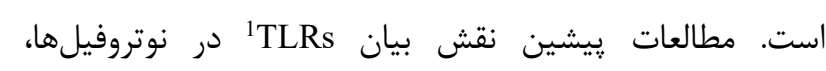

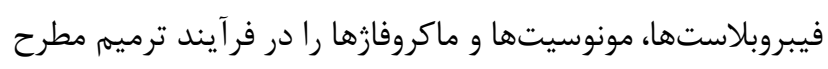

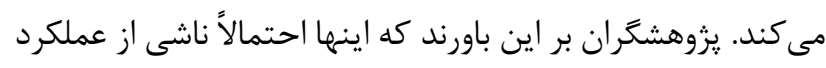

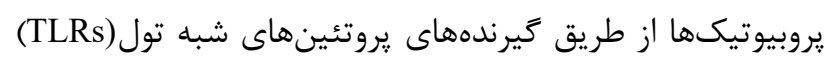

است كه نقشى كليدى در سيستم ايمنى ذاتى دارند (•r).

ميزان رَزايى و افزايش تعداد عروق خونى يكى از موثرترين

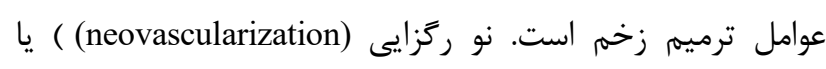

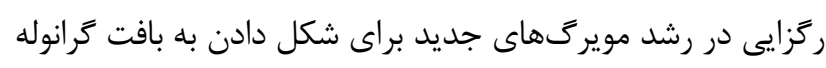

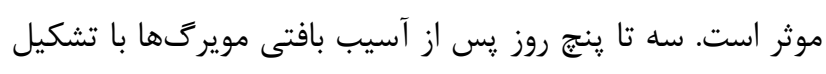

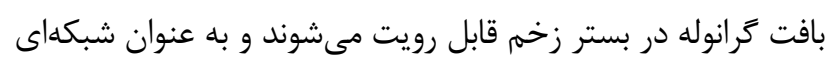

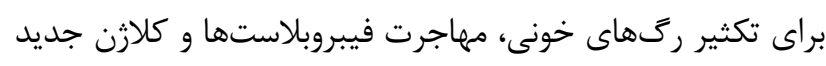

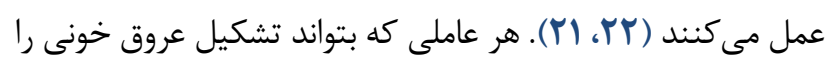

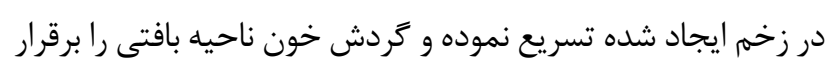

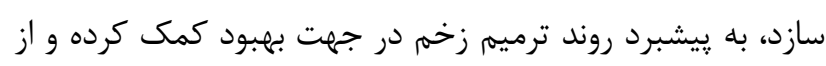

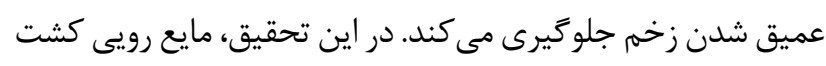

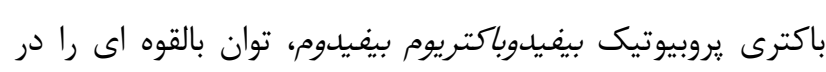

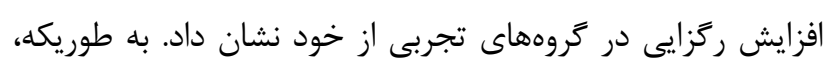

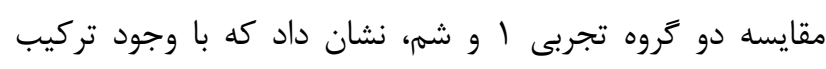

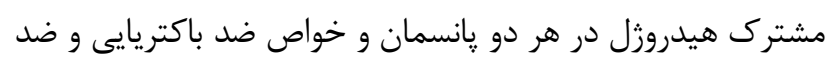

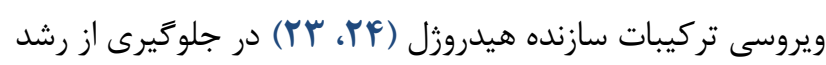

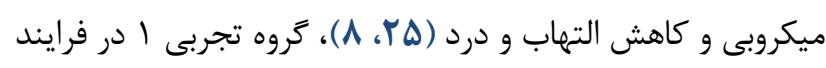

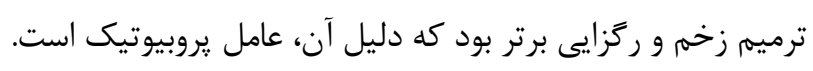

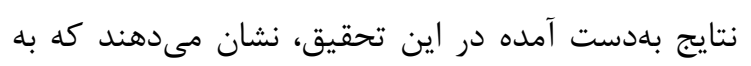

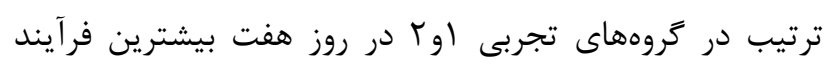

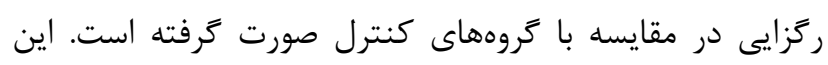

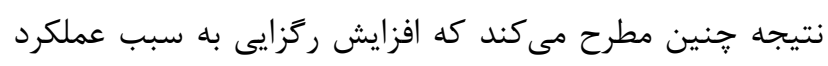

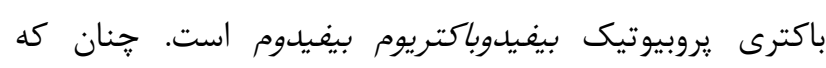

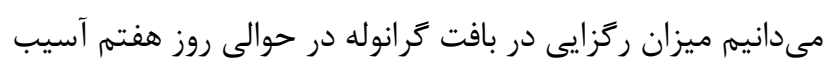

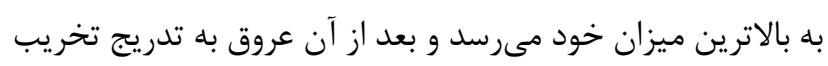

كوارشى و بررسىهاى اندكى كه بر روى بيفيدوباكتريومها با هدف

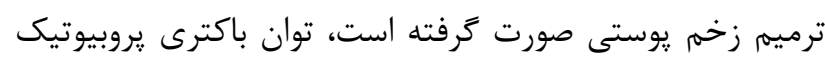

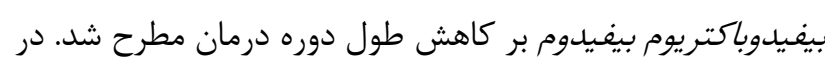

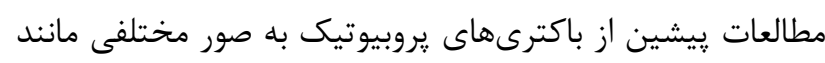

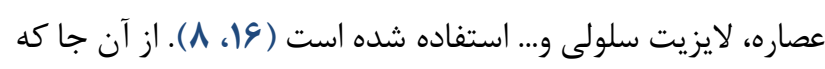

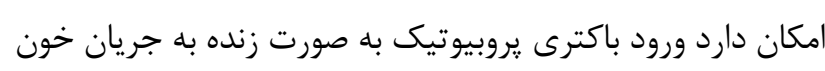

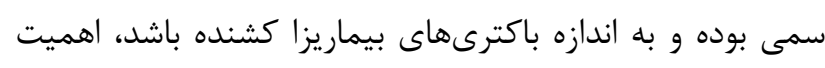

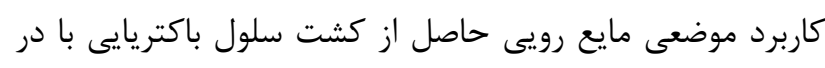

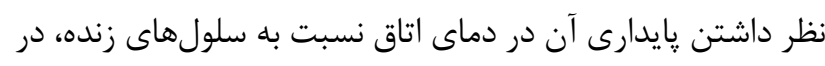

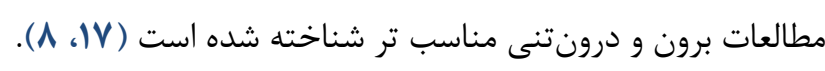

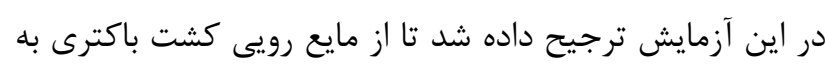

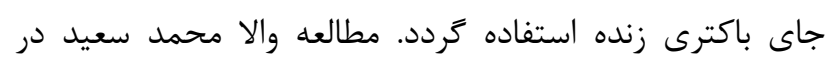

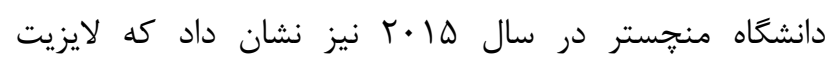

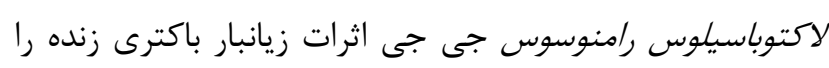

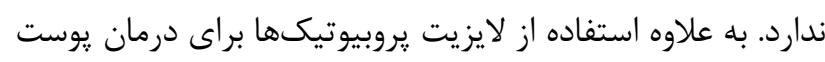

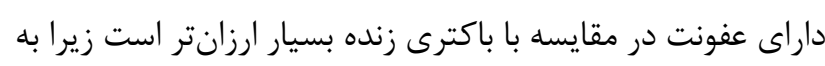

حفظ و نكمهدارى باكترى به صورت زنده نيازى نيست (1). در آزمايش برونتنى مطالعه حاضر، بf

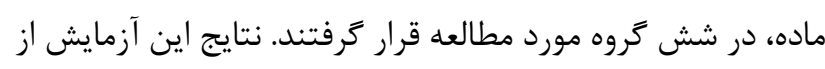
نظر شاخصهاى قطر زخم و تعداد عروق خونى ارزيابى و تحليل

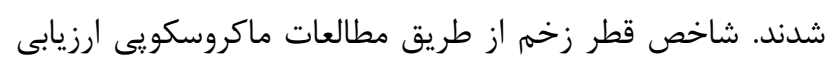

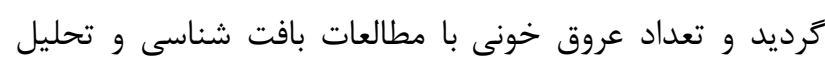

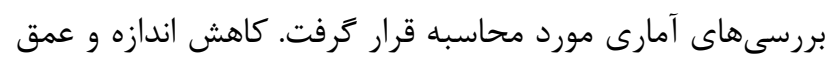

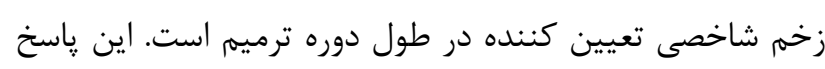

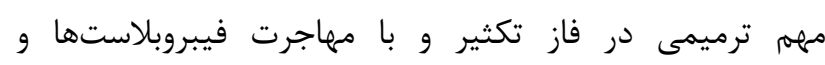

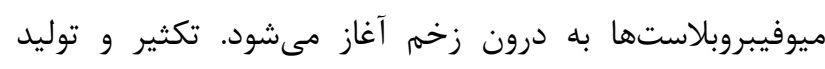

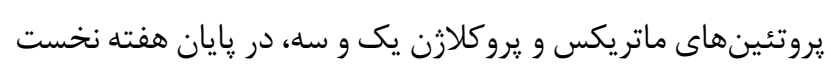

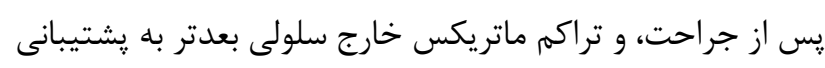

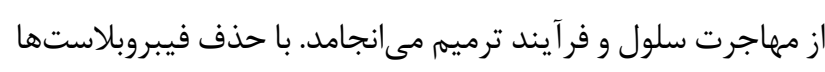

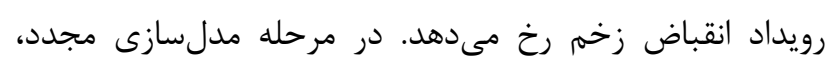

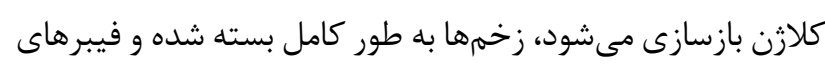
كلازن براى كاهش ضخامت اسكار در هم تنيده مىشوند (19، 19، (1).

مطالعه حاضر نشان داد كه كاربرد باكترى يروبيوتيك

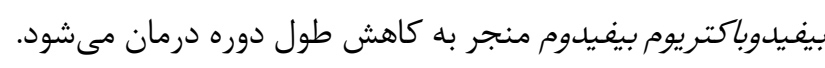

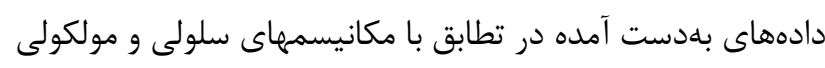

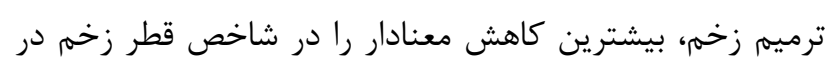


يلاسماسل ها، موجب تحريك توليد TNF-a و ركزايى در فاز

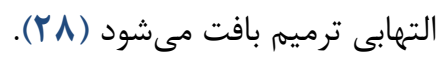
همجنين در مطالعه حاضر مقايسه درون گَروهى بين گروههاى

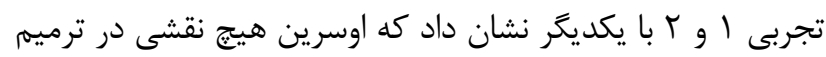

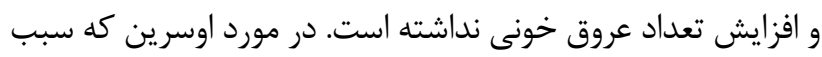

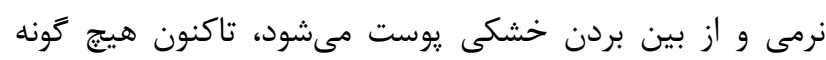

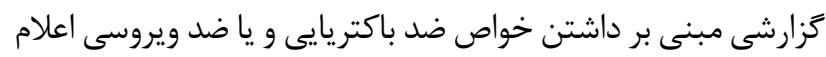

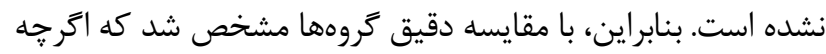

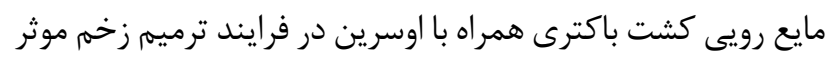

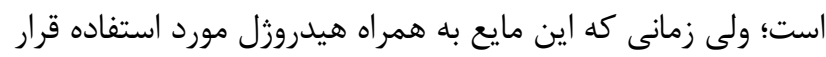

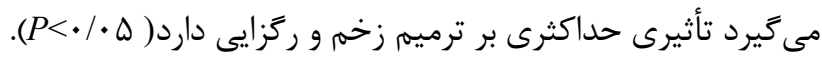

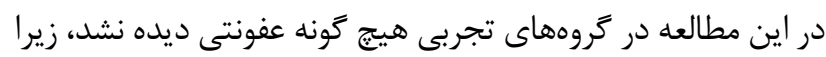

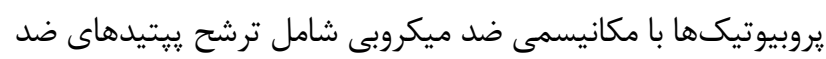

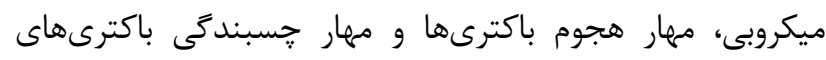

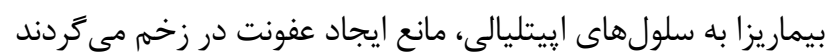

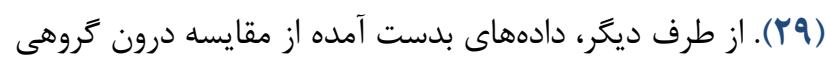

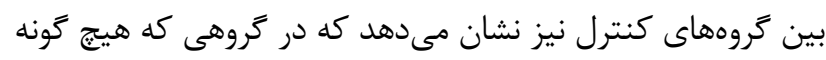

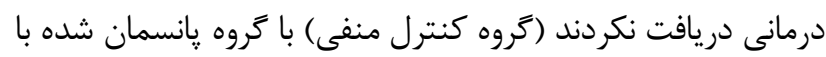

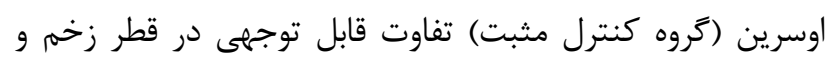
تعداد عروق خونى مشهود نبود. به طور كلى، نتايج اين مطالعه نشان داد كه افزايش ركزايى

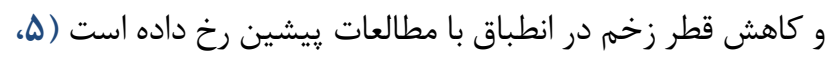

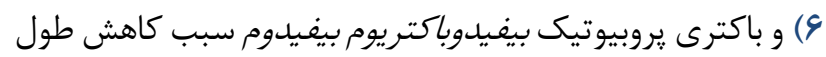

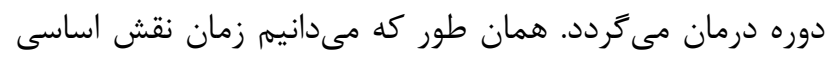

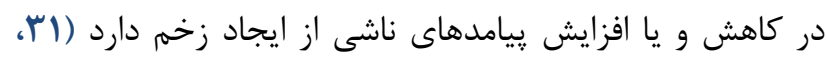
•

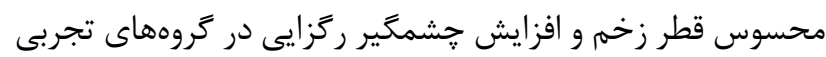

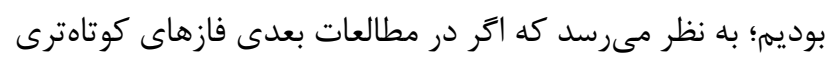

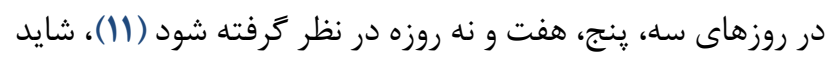

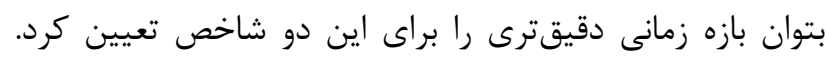

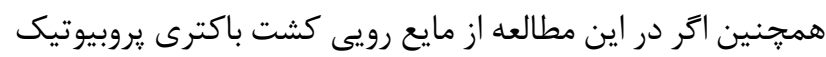

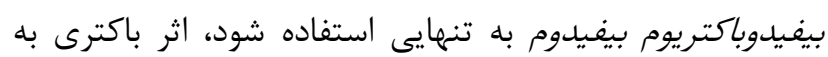
تنهايى نيز قابل بررسى خواهد بود.
مىشوند، در اين آزمايش هم بيشترين ميزان رَزايى در روز هفت

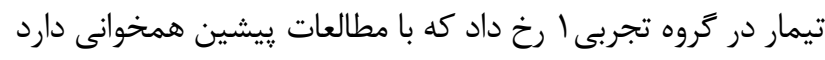

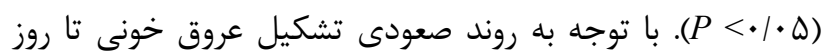

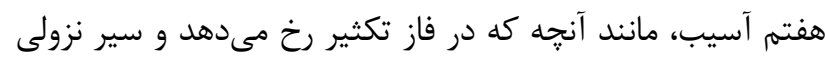

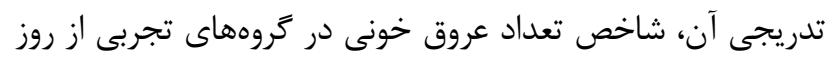

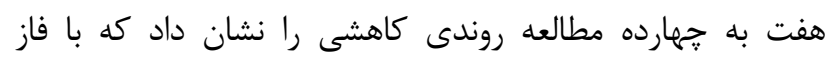

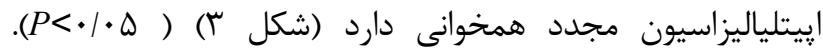

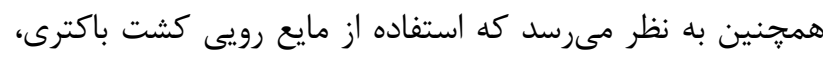

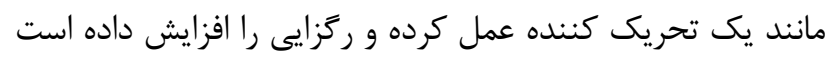
(شكل ץ). مطالعات بيشين نشان داده است كه فعاليت ركزايى

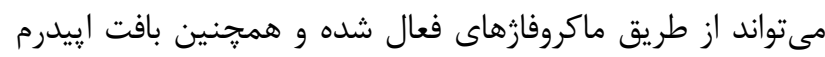

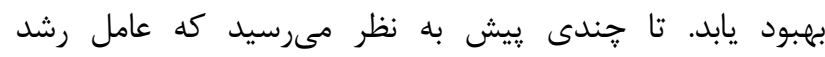
فيبروبلاست اسيدى يا عامل رشد فيبروبلاست پايه، مسئول اين باين

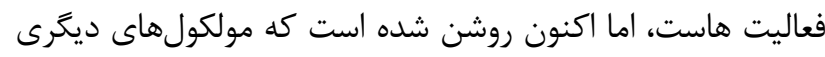

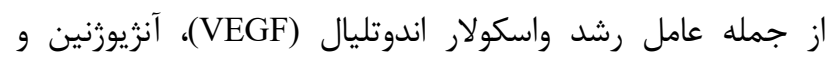

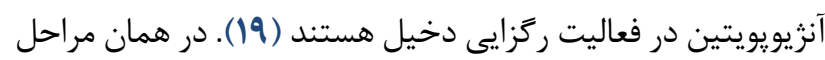

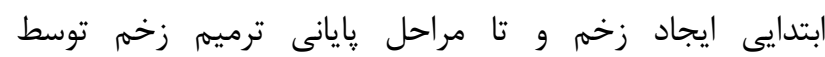
كراتينوسيتها توليد مىشود. فيبروبلاستهاى فعال شده، ماست

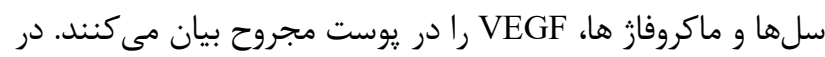

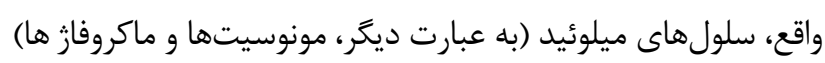

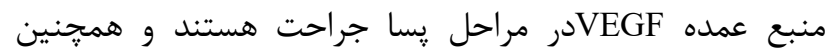

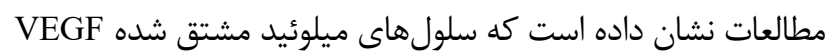

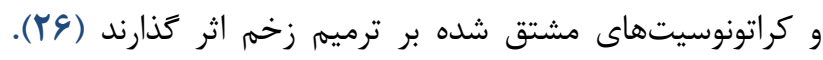

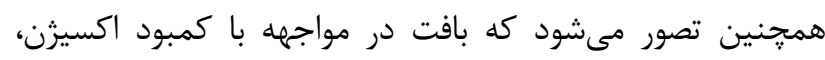
ماكروفازها را براى ترشح عامل رشد VEGF تحريك مى كند (^).

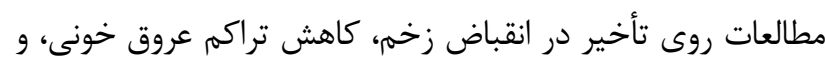

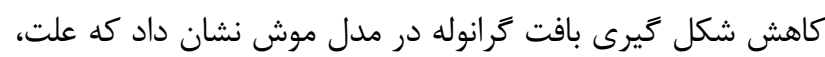
فقدان VEGF در سلولهاى ميلوئيد و كراتينوسيتها بوده است.

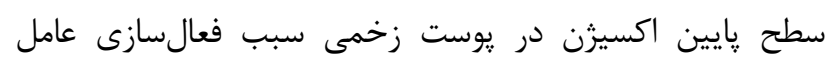

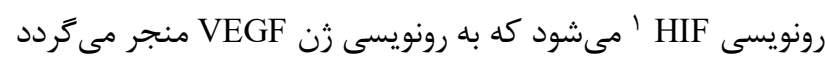

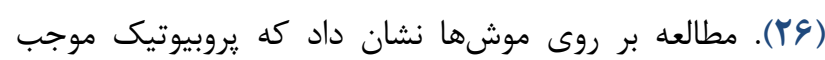
افزايش بيان عامل رشد VEGF و عامل رشد تبديل كننده بتا (TGF)

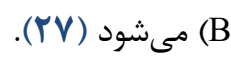

بررسى هاى هالير و همكاران (Halper et al.) نيز نشان داد

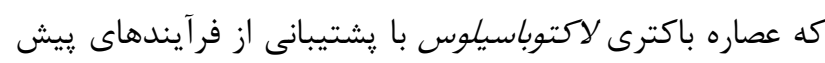

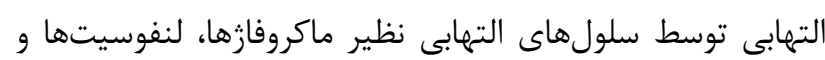

\footnotetext{
${ }^{1}$ Hypoxia Inducible Factor
} 


$$
\text { سياسگزارى }
$$

اين مقاله تحقيقى از پايان نامه كارشناسى ارشد خانم يُاه

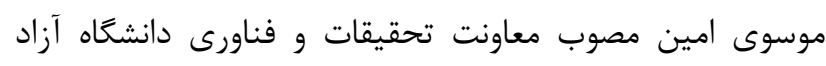

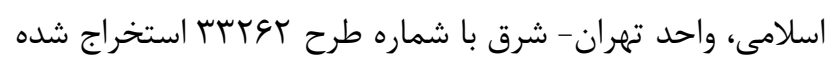

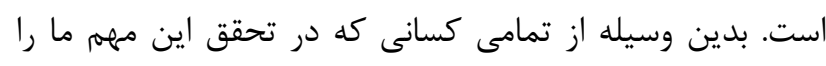

$$
\text { يارى كردند قدردانى مىشود. }
$$

$$
\text { تعارض در منافع }
$$

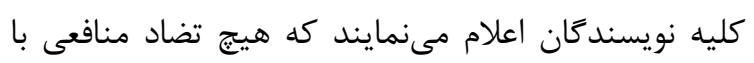

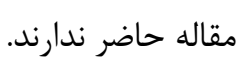

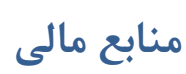

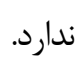

$$
\text { نتيجه }
$$

نتايج مطالعه حاضر نشان مىدهد كه باكترى يروبيوتيك

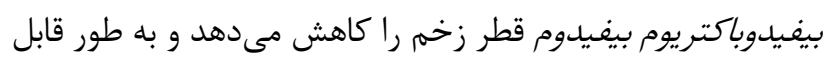

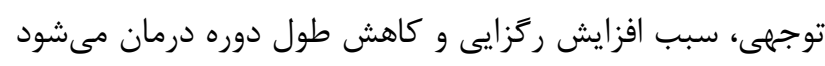

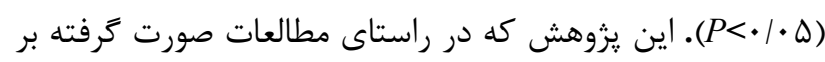

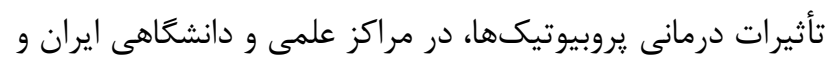

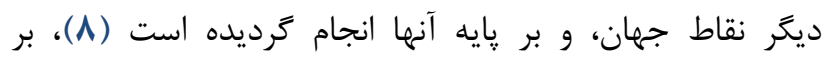

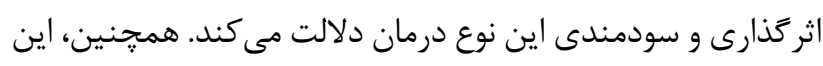

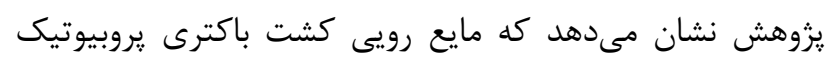

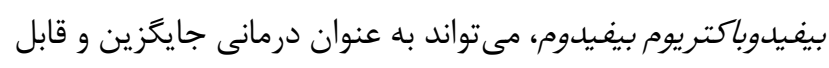

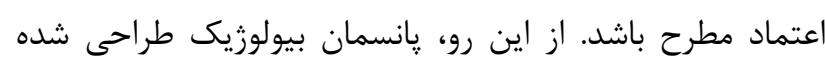

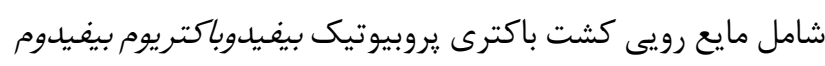

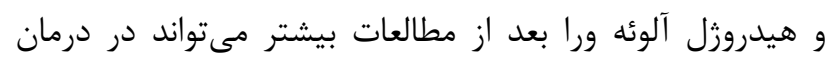
زخمهاى حاد استفاده شود. 